\title{
Introduction to the Non-dualism Approach in Hinduism and its Connection to Other Religions and Philosophies
}

\author{
Sriram Ganapathi Subramanian \\ S2GANAPA@UWATERLOO.CA \\ Department of Electrical and Computer Engineering, University of Waterloo, Waterloo, ON, Canada \\ Benyamin Ghojogh \\ BGHOJOGH@UWATERLOO.CA \\ Department of Electrical and Computer Engineering, University of Waterloo, Waterloo, ON, Canada
}

\begin{abstract}
In this paper, we introduce the Hinduism religion and philosophy. We start with introducing the holy books in Hinduism including Vedas and Upanishads. Then, we explain the simplistic Hinduism, Brahman, gods and their incarnations, stories of apocalypse, karma, reincarnation, heavens and hells, vegetarianism, and sanctity of cows. Then, we switch to the profound Hinduism which is the main core of Hinduism and is monotheistic. In profound Hinduism, we focus on the non-dualism or Advaita Vedanta approach in Hinduism. We discuss consciousness, causality, Brahman, psychology based on Hinduism, supportive scientific facts for Hinduism, the four levels of truth, and Maya. The four paths of knowledge, love, karma, and meditation are explained as well as the cosmic mind, the subtle body, and Aum. The risks for every path are also explained. Then, we introduce the orthodox and heterodox Indian schools including Yoga, Nyaya, Advaita Vedanta, Vishishtadvaita, and Dvaita. Connections to some other religions including Buddhism, Jainism, Sikhism, Judaism, Christianity, Islam, Islamic mysticism, and Zoroastrianism are analyzed. Finally, we explain the connection of Hindu philosophy with the Greek, western, and Islamic philosophies which include the philosophies of Plato, Aristotle, Plotinus, Spinoza, Descartes, Hegel, Schopenhauer, Avicenna, Suhrawardi, and Mulla Sadra.
\end{abstract}

Keywords: Theology, Hinduism, Advaita Vedanta, Nondualism, Consciousness, Path of Knowledge, Path of Love, Path of Karma, Path of Meditation, Religions and Philosophies

\section{Introduction}

Hinduism is a holy religion which is mostly based on logic and philosophy. Therefore, it is also called Hindu philosophy. The religious leaders of Hinduism were all philosophers. A well-known example is Adi Shankara (Menon, 2004) who was a great philosopher. Hinduism has changed many lives and affected many people such as Steve Jobs (Lakin, 2015) before he founded the Apple company.

Hinduism has two versions for two levels of truth which will be explained in this paper. The two versions are simplistic Hinduism and profound Hinduism. The simplistic Hinduism is like a shell around the profound Hinduism which is the core. The simplistic Hinduism is used for teaching children and the public to get them ready to understand the complicated philosophy of profound Hinduism. The simplistic and profound Hinduism are henotheistic and monotheistic, respectively. As the main Hinduism is the profound Hinduism, this religion is monotheistic.

In this paper, we cover both simplistic and profound Hinduism. We also mention the details of Hinduism theology, culture, and philosophy. Hinduism has several schools including Advaita Vedanta which has a non-dualism approach. The profound Hinduism explained in this paper is based on the non-dualism approach or Advaita Vedanta. We also briefly introduce other schools of Hinduism. The connection of Hinduism to other Indian schools and other religions is also explained.

\section{Holy Books}

There is not only one holy book in Hinduism but there is a series of holy books which are extremely long all together. Sometimes, the name Vedas is used for referring to the whole series of holy books in Hinduism. The Vedas were mostly transferred from a generation to the next generation verbally. Therefore, the Vedas are also called Shruti which means "which is heard". There were two reasons for not often writing down the Vedas:

1. In very ancient times, they had to write on some leaves

The materials in this paper do not reflect the beliefs of the authors of the paper. This is merely a research paper in theology and the authors have written it after studying and researching about different religions including Hinduism. Work is in progress; comments are welcome. The authors contributed equally to this work. 
which were perishable during time. Therefore, writing was very hard because of lack of equipment.

2. India faced many wars (Dikshitar, 1999) where attackers used to destroy and fire their books.

Gradually, Vedas were written down although people still usually learn them verbally from their teachers. The Vedas are very old and no one knows the exact date of their composition.

\subsection{Vedas}

\subsubsection{PARTS OF VEDAS}

Vedas, as was mentioned, are Shruti. The Vedas contain four main parts which are:

1. Rg-Veda (Rigveda)

2. Yajur-Veda

3. Sama-Veda

4. Atharva-Veda

Most of the first portions of all four parts of Vedas are the ritualistic Vedas, called Purva Mimamsa or just Mimamsa, which are the religious instructions for life. A few final portions of all four parts of Vedas are the Vedanta, also called Uttara Mimamsa, which is introduced in the following.

\subsubsection{VEDANTA (UPANISHADS)}

Vedanta is the heart of Hinduism (Torwesten \& Rosset, 1994). It is also referred to as Upanishads. The word Vedanta means the end of the Vedas. The Vedanta is the philosophical part of Vedas which explains the ritualistic portions of Vedas with logical experiments and explanations (Deussen, 1906). The deep explanations of Hinduism can be found in Vedanta.

\subsection{Smrutis}

In addition to the Vedas (Shruti), there are some holy books which were written. They were examples and stories to illustrate the interpretations of Vedas. These tales simplify the profound Hinduism in the form of stories to be understandable by the public and children. These holy books are named Smrutis which means "written" because they were written by authors and poets.

\subsubsection{SMrUtis FOR VEdAs: LAWS OF MANU}

There are Smrutis for both ritualistic Vedas and Vedanta. The stories for understanding the ritualistic Vedas is in the book "Laws of Manu" (Bühler, 1886). Manu was a sage who wrote the book.

\subsubsection{SMRUTIS FOR VEDANTA: ETAHAS AND PURANAS}

The story books for understanding philosophical Vedanta are mostly relied on an incarnation of Vishnu (see Section 3.4). These books are divided into two categories:

1. Etahas: Etahas means that the incarnation of Vishnu was alive at the time the book was being written about them.

2. Puranas: Puranas means that the incarnation of Vishnu was not alive at the time the book was being written about them.

We have two Etahas which are:

1. Ramayana: this book is written by Valmiki (Goldman \& Goldman, 2009) and is about Rama (see Section 3.4).

2. Mahabharata: this book is written by Vyasa (Rao, 1981) and is about Krishna (see Section 3.4).

Example 1. There was a monk who was praying under a tree. A thief came to him and said he must give him money. The monk said he does not have anything with him but if he stays here, he will bring him money from his house. As will be mentioned in Section 3.9, the monks were known for being honest so the thief accepted. The monk asked him to look at the tree and repeat "mra" over and over again. Note that "mra" means tree in Sanskrit. The thief said "mra-mra-mra-..." and after a while, the repeated phrase changed gradually to "ram-ram-ram-...". Hence, he subconsciously started to repeat the name of Ram (see Section 3.4). When the monk returned, the thief had changed completely and he quit robbery. The thief was no one but Valmiki who wrote the book Ramayana which is a part of the holy Vedas.

We have eighteen Puranas (Prasad, 2007) which areAgni, Bhagavata, Brahma, Brahmanda, Brahmavaivarta, Garuda, Kurma, Linga, Markandeya, Matsya, Narada, Padma, Shiva, Skanda, Vamana, Varaha, Vayu, and Vishnu. Vyasa is known as the composer of the Puranas. For example, Bhagavata (Gupta \& Valpey, 2013) is mostly about the childhood of Krishna (see Section 3.4).

\subsubsection{Bhagavad Gita: A Part of Mahabharata}

Bhagavad Gita (Mascaró, 2003) is a very well-known part of the book Mahabharata. In its superficial layer, it is the story of a war where the prince Arjuna is on one side of the war. His guide and charioteer is Krishna (see Section 3.4). The war is merely the background of story and the dialogues between Arjuna and Krishna form most of the book. Krishna teaches the profound philosophy of Hinduism to Arjuna. At first, Krishna starts with the very last goal of Hinduism which is "you are That" (see Section 4.2.4); however, Arjuna does not understand. Then, Krishna starts from the basics and builds up the philosophy until, at the end of book, he explains the goal of Hinduism again. This is actually the approach of Brehmen who explain Hinduism to people. They start with the highest levels of philosophy and if the person does not understand, they simplify their explanations. 


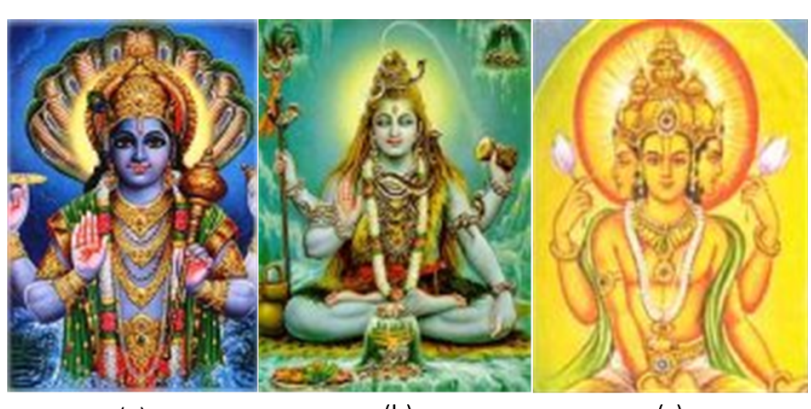

(a)

(b)

(c)

Figure 1. The three most well-known gods: (a) Lord Vishnu, (b) Lord Shiva, and (c) Lord Brahma.

\section{Simplistic Hinduism}

Simplistic Hinduism is a version of Hinduism which has simplified the meaning of religion and Hindu philosophy so the public can understand much easier. It helps people follow the instructions originated from the profound layers of Hindu philosophy. As it is a simplistic version, some parts of it can be considered as mythology (Wilkins, 1913). The simplistic Hinduism is henotheism, i.e., it believes in one God who is Brahman but worships multiple deities as images of God.

Example 2. When we want to have a map for a city, we cannot use the real distances in the map as the distances are huge. We scale everything to smaller scales and draw on the map. We also use symbols for everything. Moreover, we use legend for the map. So is the profound Hinduism and the great knowledge. It is so huge for the public to understand because human; $s$ mind is a small and weak container. Therefore, Hinduism has been scaled down and has become symbolized for people to understand better. This simplistic version is still a map and helps people prepare for understanding the profound knowledge.

\subsection{God and gods}

\subsubsection{BRAHMAN: GOD}

Hinduism might seem polytheistic at the first glance but it is completely monotheistic (Doniger, 2014). It believes in "one" God and even says that there is nothing but God. The one God is referred to as Brahman, consciousness, or Aum (Om).

As we will discuss more in Section 4.2.4, everything is nothing and only Brahman exists. Hinduism says "you are That" meaning that you are God and not this mind to which you are attached. This clearly has a mystical approach which has a monist perspective. There are no you and me. There is only one existence and that is God. Our appeared world merely borrows existence from Brahman and it is just an appearance. This is related to the profound Hinduism which will be explained in Section 4.

\subsubsection{Saguna Brahman: God With Attributes}

As was explained in Example 2, in order to map the reality, we need to scale it down, symbolize it, and use a legend. These three are the attributes which we add to the reality in order to map it. In simplistic Hinduism, in order to simplify the concept of monism and existence of Brahman, some images (or projections) of God are created exactly as we have symbols for things on the map because those complete things do not fit in the map. These images are for better understanding of God in human's mind container. Brahman does not have any attribute because He is everything and He is the whole. These images of God are God with attributes so people understand them. These images are named "Saguna Brahman" which means "God With Attributes". Note that Saguna Brahman is also called "Bhagwan" or "Ishwara". That is why we see gods and goddesses in simplistic Hinduism (Chandra, 1998). By definition, Saguna Brahman is the appearance of God in the mind and body level of truth. Hence, the Saguna Brahman is the God or gods in the third level of truth but Brahman is in the fourth level of truth (see Section 4.7).

Three of the gods are very famous among Hindus. They are Vishnu, Shiva, and Brahma. Figure 1 shows the pictures of these three gods. In the following, we introduce these gods.

\subsubsection{VISHNU}

Lord Vishnu is the god for protecting and preserving the world. As Fig. 1 shows, Vishnu has four hands. In His hand, He has a conch (shankha), a mace (gada), and a discus (chakra). He blows in the conch to remind people of having kindness and compassion. The mace is His energy to sustain the world. He protects the world from the evil by His discus. He has four arms, two of which is for protecting the physical world and two others for protection of the spiritual world. The blue sky behind Him shows that He has control on the infinite world. The blue color of His body shows that He has infinite characteristics and attributes.

He usually is shown standing on a snake with many heads. The snake symbolizes the evil and the bad desires of people. He stands on the snake to control people's desires and the evil.

\subsubsection{SHIVA}

Hinduism believes that the world goes in cycles meaning that a world starts and then after a cycle, it is ended and another world starts. The good and evil in the world have some balance. When the balance is changed and the world suffers from the evil, Lord Shiva decides to destroy the world to end the suffer. Therefore, He is considered as the destroyer or death judge.

As Fig. 1 shows, Shiva's body is covered by ash which symbolizes the physical world originated from Him. He has three eyes, two of which show the control over the 
physical world and the one on His forehead shows control on the spiritual world. His ear rings are different in His ears; one as a symbol of man and one for woman, meaning His control on the world of both genders. A snake is around His neck symbolizing the freedom in yoga. Shiva is the god especially for yoga (see Section 6.3). The snake carries nothing and is free so it is a symbol for yoga which frees human and mind from everything and focuses on the truth. The tiger skin which Shiva wears is a symbol for His power. When, Shiva closes His eyes, the cycle of the world is over. His eyes are half open in the figure showing that the current cycle is going on.

\subsubsection{BRAHMA}

Lord Brahma is the creator of the world. At the start of every cycle of the world, Lord Vishnu and Lord Shiva choose a new Brahma. Brahma creates the world to start the new cycle of the world. He has four faces as symbols for the knowledge of the four Vedas (see Section 2.1.1). This knowledge helps him create the world. He has four hands representing the four characteristics of human's personality, i.e., mind, intellect (very self), ego, and the empirical self or conditioned consciousness. His body has a golden color showing his activity in creation. He has lotus in his hand as a symbol for all the living beings created in the world. In general, Brahma is a symbol for the mind and creativity.

\subsection{Some Other gods}

There exist many gods and goddesses in the simplistic Hinduism as images of God so the public understands the profound philosophy of the one existing God better and move toward that deep knowledge. Here, we mention some of these gods and goddesses as examples:

- Saraswati: She is the divine consort of Brahma. She is the goddess of wisdom and knowledge. She helps Brahma in terms of knowledge for creation of the world.

- Mahadevi: She is the great goddess who is the sum of all goddesses.

- Lakshmi: She is the goddess of wealth and the divine consort of Vishnu.

- Parvati: She is the goddess of household and motherhood. She is the divine consort of Shiva.

- Kali (with long [a]): She is the goddess of time, creation, destruction, and power. She destroys the evil and is the divine consort of Shiva.

- Ganesha (Ganapati): He is the divine son of Shiva and Parvati. He has the head of an elephant and body of a human, as symbols of wisdom of head and kindness of heart, respectively.

- Indra: He is the god of storms. He fights the devils.

- Agni: He is the god of fire. He brings the offerings to the heavens through fire.
- Varuna: He is the god of truth and moral judgements. He knows all the secrets of beings.

\subsection{Yuga: The Four Ages of World}

According to Hinduism, the world repeats in cycles. Every cycle of the world, named Yuga (Prophet \& Prophet, 2006), has four ages which are Satya Yuga (age of truth), Treta Yuga, Dvapara Yuga, and Kali Yuga, in order. The current age of this world is the last age, i.e., the Kali Yuga. The first and last ages are the purest and worst ages of the world. In the last ages of the world, the bad dominates the good and the human's mental ability decreases (e.g., humans could previously memorize or read a huge amount of manuscripts).

\subsection{Avatars: Incarnations of Vishnu}

Lord Vishnu has been appeared on the earth in various periods of time in the four ages of the world. These appearances are referred to as the incarnation of Vishnu and the appeared ones are named avatar (Mathew, 2005). In the current cycle of the world, the nine incarnations have come to the earth and the last one, i.e., Kalki, will come in the future as promised (González-Reimann, 2016). All the incarnations are respectful and holy; however, the first incarnations are believed to be purer and better. The ten incarnations of Vishnu, in order, are:

- In Satya Yuga:

1. Matsya: incarnation as a fish. He is analogous to Noah in the Bible.

2. Kurma: incarnation as a tortoise.

3. Varaha: incarnation as a boar or a pig. At that time, the Vedas (knowledge) were stolen by the demons and Vishnu recovered the stolen Vedas.

4. Narasimha: incarnation as half man and half lion. At that time, Vishnu destroyed a demon which had become immune against the attacks of humans and gods.

- In Treta Yuga:

1. Vamana: incarnation as a dwarf. At that time, a demon, named Bali, upraised and took all the earth and heavens and fired gods from the heavens. Vishnu, as a dwarf, tricked Bali to give Him the lands in His three steps. Then, the dwarf grew a lot and took the earth in one step and the heavens with another one. Hence, He got back the earth and heavens.

2. Parasurama: incarnation as a hunter. At that time, the earth became very sinful and irreligious. Vishnu saved the earth as a hunter.

3. Rama (Ram): incarnation as the prince and king of Ayodhya. Ram was very virtuous. According to Ramayana (see Section 2.2.2), King Ravana, was an evil king who kidnapped Ram's wife, named Sita. Vishnu, as Ram, killed Ra- 
vana.

- In Dvapara Yuga:

1. Krishna: incarnation as a mentally advanced man. According to Mahabharata, Krishna was a very wise man whose teachings of the profound philosophy of Hinduism can be found in Baghavad Gita (see Section 2.2.2).

- In Kali Yuga:

1. Buddha or Balarama: incarnation as an allknowing or complete person. Buddha found the four noble of truths and reached Nirvana (see Section 7.1). Some categorizations consider Balarama, who was a brother of Krishna's, as the ninth incarnation of Vishnu, instead.

2. Kalki: incarnation as the promised man with a sword and on a white horse. He is expected to appear and form the apocalypse (see Section 3.6).

\subsection{How Life Started}

According to the book Bhagavata (see Section 2.2.2), at the start of life, two groups of divine and asura (demon) people existed. The good people and demons had fight for obtaining a divine nectar of eternity. Lord Shiva sided the good people in the fight. The instruction for obtaining the nectar was to grain some divine seeds by both the good and bad sides so they decided to cooperate and grain the seeds. When the seeds were grained, a poison came out first which must had been drunk by someone. Lord Shiva drank the poison but grabbed a snaked and put it around his neck so that the poison remains in his throat. That is why a snake is around His neck in the pictures of Shiva (see Fig. 1-b). Afterwards, the good people cheated on the demons and drank the nectar; however, it was not enough and just half of them drank and became eternal gods. The non-eternal good people and the demons created the humans where every human was half good and half evil encouraging to good and bad attitudes. Since then, humans remain in the reincarnation cycles of life. Note that this is the story of start of life in simplistic Hinduism. For the start and end of the world in profound Hinduism's perspective, refer to Section 4.8.3.

\subsection{Kali Yuga and Apocalypse}

According to the Bhagavata Purana (see Section 2.2.2), the last and worst stage of the world, Kali Yuga (see Section 3.3), started by the death of Krishna which was the end of Dvapara Yuga stage. The date of that time was February 17th, 3102 BCE (Yano, 2003). The end of Kali Yuga is the apocalypse (De Bary, 1958). In apocalypse, a demon, named Kali (with short [a]), arises and acquires the power. In the Kali Yuga, the avatar Kalki exists (see Section 3.4). According to a Purana, named Kalki Purana (Das, 1913), Kalki fights Kali. By destroying the devil Kali, the world is prepared for being ended. Therefore, Lord Shiva (see
Section 3.1.4) destroys the world so the next cycle of world gets created by Lord Brahma (see Section 3.1.5).

\subsection{Karma}

Every piece of work, whether good or bad, has a reward. The reward is called karma in Hinduism (Sharma, 1973; Keyes et al., 1983). Depending on whether the work is good or bad, we can have good and bad karma.

\subsubsection{BAD KARMA}

If human does a bad thing, they gain a bad reward because of that. This karma is a bad karma. This is the most obvious karma to understand because people believe that doing bad things will get back to them.

\subsubsection{GOOD KARMA}

In case people do a good thing, they gain a good karma if they enjoy doing it or if they do it to show off to others. For example, if someone helps the poor to show off, they gain good karma; however, if he helps the poor in private, not any karma is gained.

\subsubsection{NO KARMA}

If people do not do any bad thing and do the good works without any joy or benefit, they do not gain any karma. Having no karma is the best ideal for a human in the Hindu philosophy.

\subsection{Reincarnation, Heavens, and Hells}

Apart from life on the earth, there exist six heavens and six hells. The most top heaven is paradise. In Hinduism, the heavens and hells are known to be far from the earth in the physical space where the lower-level heavens and higherlevel hells are closer to earth in terms of physical distance. Every human has a subtle body (see Section 5.4.3) which is born in a new body in a heaven, hell, or on the earth after the death of its physical body. When a human dies, he goes to a heaven or a hell depending on whether he has collected more good or bad karma, respectively (Doniger \& O'Flaherty, 1980). The more good and bad karma result in a better heaven and a worse hell, respectively. After he passes his joy in heaven or suffers in hell to clear his karma, he is reborn on the earth in a new body. Therefore, human has lives in cycles. Going through the cycle of repeated births and deaths is named reincarnation or "samsara". The world has seen some people who remember their previous lives (Stevenson, 2000). That is because memory is in the subtle body (see Section 5.4.3). It is very hard for people to remember their several past lives as the time distance is too much for the memory to remember.

In parentheses, note that in some branches of Hinduism, and also in Buddhism, it is believed that the good and bad rewards are given to the human in his next life on the earth (Kaufman, 2005). For example, if a person is a bad or good 
person, he will suffer from a disease or will be blessed in his next life, respectively.

The beauty of this philosophy is that when a human does not have collected any karma or if his karma is negligible, he becomes free of the reincarnation and goes to the paradise after the death of his body. There is no return from paradise as it is eternal. This is the reward to someone who does not do any bad work and does good works without collecting any good karma. The person who has gained this stage of knowledge that he should not collect any karma and will go to paradise is known as "moksha", or "jivan mukta", or "mukta". The literal meaning of jivan mukta is "free while living". A moksha is unified with the God Brahman. We will discuss this more in Section 4.

\subsection{Brahmin, Monk, and Rishi}

In Hinduism, the person who knows Brahman is named Brahmin. Brahmin means "a person who knows Brahman". They teach people the profound Hinduism (see Section 4) and the fact that everything is Brahman. Some of them preach in temples and people ask their religious problems from them in temples. As a symbol, Brahmins have a necklace made of white thread which is named holy thread. Note that Brahmin, Brahman, and Brahma are different. Brahmin is the person who teaches Hinduism, Brahman is the consciousness or God, and Brahma is an image of God. The people who live a holy life and dedicate their lives to refinement and Brahman are called monk or sage. The monks never get married. The monks are well-known for their well behaviour, trustworthy, and honesty because they never lie. As will be explained in Section 5.4.3, some monks, who have very powerful and concentrated minds, answer people's problems through telepathy without talking a single word. The monks usually wonder in different places and do not stay in a particular place; however, they have some training centers which are named Ashram or monastery. A person who dedicates their life to profound Hinduism and Brahman is called rishi. A rishi can get married. Rishis usually live in forests but they can live anywhere.

The qualifications for becoming a Brahmin, monk, and rishi are different. The lowest standard is for Brahmin. Brahmins are mostly automatically selected as Brahmin if their parents are Brahmin. Apart from this family-wise selection, other people can also become Brahmin if they want to. If Brahmins want to preach in the temple, they should pass some qualifications tested by some teachers in the teaching centers. The harder standards are for monks and they should be approved to become a monk by another monk. The hardest qualification is for rishi. Nowadays, rishis do not exist.

\subsection{Special Clothes for Temple}

When people enter the temple, they should wear a special piece of clothes. The special clothes of men and women are different. Men should wear dhoti which is worn for covering the legs. Dhoti is either white or saffron. Men should not wear any shirt in the temple. Women wear saree which is like a dress and can have any color. The male monks should wear saffron dhoti while the female monks usually wear some clothes similar to saree.

\subsection{Vegetarianism}

The Hindus are vegetarian, i.e., they do not eat meat but they use the product of animals such as milk (Spencer, 1996). There are two reasons for the vegetarianism in Hinduism:

1. It is believed that the animals which eat meat are more angry than the animals consuming vegetables. For example, lion is usually angry and anxious but elephant is often very calm. Human's body is considered as animal in Hinduism so it is impacted similarly by eating meat. People who eat meat try to control their anger by means of different tasks such as meditation.

2. Eating meat results in harming and hurting the animals by killing them. This reason, known as the meat paradox (Loughnan et al., 2012), is also provided by non-religious vegetarians nowadays.

\subsection{Sanctity of Cows}

In Hinduism, the cows are sacred (Brown, 1957; Krishna, 2010). We explain the reason in the following. As was mentioned, the Hindus are vegetarians but they use milk. The animal whose milk is often used is cow. In order not to harm the cows when milking them, the monks of Hinduism ordered people to treat them respectfully. Note that if someone understands the profound Hinduism (see Section 4), he will not harm anybody and anything including the cows; however, this order was announced for the low knowledge level of the public.

\section{Profound Hinduism}

Profound Hinduism is the main Hinduism which has a very deep philosophy and includes both logic and mysticism. Gaining the knowledge of profound Hinduism is the goal which should be attained and then performed in life. In the following, we introduce the profound Hinduism.

\subsection{Consciousness}

Consciousness is one of the most challenging subjects in philosophy (Chalmers, 1995; 2007). It is the the ability to understand, feel, and absorb the world. As we will discuss in Section 5.4.1, Hinduism considers consciousness separate from and above the mind while sometimes mind and consciousness are taken to be the same in science (Jack- 
endoff, 1987).

\subsection{Causality}

According to definition, two things are "different" if they can be shown separately. We use the terminology of difference in our explanations.

Example 3. The pot and hand are different as they can be shown separately. However, clay pot and clay are not different as we cannot show clay pot without clay. Another example is gold and golden jewelry which are not different.

Note that if two things are different, they are not the same but the opposite is not necessarily true, i.e., two things can be not different but not the same. In other words, "not different" is a subset of "the same".

Example 4. A clay pot and clay are not different as we cannot show the clay pot without clay. However, clay and clay pot are not the same.

A characteristic is "intrinsic" to something if it has always been with that thing. If the characteristic is borrowed from something else, that characteristic is "extrinsic". The extrinsic characteristic is borrowed and entered to the thing at some time and it may go away at some future time; however, an intrinsic characteristic is always with the thing.

Example 5. Imagine an iron pot, some water in it, and a potato inside the pot. We put the pot on the fire. The pot, water, and the potato become hot. The heat is an extrinsic property for pot, water, and the potato as they have borrowed it from fire; however, heat is an intrinsic property of fire as fire cannot be imagined without heat.

\subsubsection{Material Causes Consciousness?}

Causation (Lewis, 1974) of B by A means that A was prior to $\mathrm{B}$ in existence and it has gave existence to $\mathrm{B}$. The $\mathrm{A}$ and $\mathrm{B}$ are named the cause and effect in causation. In causation, B borrows some extrinsic characteristics from A. The atheists believe that material has caused consciousness during evolution; the humans have evolved to intelligent beings by cross over, mutation, and other environmental impacts. In this section, we mention how Hinduism falsifies this claim. Causation of $\mathrm{B}$ by $\mathrm{A}$ requires $\mathrm{A}$ and $\mathrm{B}$ to have interaction; otherwise, B cannot borrow characteristics from A. Now, assume A and B are material and consciousness, respectively. However, a contradiction occurs as material and consciousness are different in essence so they cannot interact. Therefore, material cannot cause consciousness.

Example 6. Some people might say that the brain causes consciousness in human and animal. They say that the functionality of brain can be observed by functional Magnetic Resonance Imaging ( $f$-MRI) during conscious decisions. The answer to this problem can be clarified by an example. When we see some people have entered a building, do we say that the door through which they have passed has caused them? No, they have passed the door and appeared in the building. The same thing happens in the brain. The mind and brain are the gates where the consciousness comes through to enter the body.

\subsubsection{Consciousness Causes Material?}

Abrahamic religions claim that consciousness has caused the material, i.e., a conscious entity which is God has created the world. Hinduism falsifies this claim, too. The discussion in the previous section is also usually used by religions to falsify the evolution and atheism. They say that material cannot cause consciousness because of not having interaction for the different essences. However, the same reason can be used to falsify the fact that consciousness causes material. As the essences of consciousness and material are different, they cannot interact; hence, consciousness cannot cause material.

Hinduism criticises the Abrahamic religions when they ask the question that who created or caused the world. It says that this question is already making an assumption that the world exists. In other words, where does this assumption come from and why is it necessarily true?

\subsubsection{EVERYTHING IS CONSCIOUSNESS}

We explained that neither does material cause consciousness nor does consciousness cause material. Hinduism believes that there exists nothing but consciousness, i.e., material is "the same" as consciousness. In other words, everything is consciousness. The material and everything is appearances of consciousness. The consciousness transcends the material, this world, and humans. The world borrows its existence from the consciousness.

Example 7. The wave and ocean are not different but they are not the same. The ocean transcends the wave as wave borrows its existence from it. The wave is an appearance of water in ocean.

\subsubsection{BRAHMAN: YOU ARE That!}

The only thing that human eye cannot see is the eye itself. Note that seeing the eye in the mirror is the reflection of eye and not the eye itself. When the eye sees an object, the light is reflected from the object to the eye and because of the visual nerves in the brain, the object is seen. Now the question is whether "me" is the brain or mind or whether "me" is a higher level than the mind? Hinduism says yes.

When a human is asleep and dreams in his sleep, he sees himself in the dream but the dream is not real. Hence, the world in his dream is existing in his mind. He is different from his mind because he sees himself in the dream.

Hinduism says that the "me" is the consciousness which is above the mind/brain. Every human is the entire consciousness and not a part of it. This is not selfish as everybody is the entire consciousness. This even makes people kind and close to one another as they know that they all are the same 
and are the consciousness. The consciousness is named God or Brahman. This consciousness is the only thing that exists and the world is an appearance of this world which borrows its appearance from the consciousness.

Hinduism says that "you are the ocean and this world just seems to be a wave on this ocean". Notice that it says "seems to be" meaning that this world does not exist and is our imagination (appearance). In summary, Hinduism says "you are That" which means that you are Brahman and everything is Brahman. Also, Hinduism says that "nothing can even scratch the surface of who you are".

Note that understanding this might be difficult for some people because their minds are used to this world by habit and they think this world is real and there is no Brahman. But if they think differently against their habit, they can shed light to their understanding.

Example 8. Consider a mirage in a desert which someone sees and thinks that it is real. He strongly believes that the mirage is really water because he is seeing it. But when he goes near it, he finds out that the mirage was just an appearance and not real! So is the world.

Example 9. Consider a rope at a corner of the room. But because of darkness, someone thinks that it is a snake and gets frightened. Then, a friend tells him that it is just a rope. Don't worry! But he keeps saying that no you are wrong! It is a snake. He asks his friend whether the snake has poison or not. His friend answers: what are you taking about as it is not a snake? Your question is not important. This is what happens when people are busy with the problems of life, not noticing that it is not real and just an appearance. The relation of the rope and snake is only foolishness or ignorance because there is no any snake! So is the relation of me and my embedding body.

\subsection{Psychology: Why Are You Sad or Angry!?}

Example 10. When a movie is shown on a screen, the characters of movie are not real! The movie and its world is just an appearance on the screen. Whatever happens in the movie, whether a character is sad or happy or dies, has not a single effect on the screen.

In the previous example, the screen and the movie are like the consciousness and the world, respectively. So, whatever happens to you or the world, why are you affected? Why do you get angry, sad, or happy? Happiness is just borrowed from the consciousness and sadness is the absence of this borrowing. By having this knowledge, you will never get angry because you know that your mind, which is not real, gets angry and you are not your mind (Bhawuk, 2011). You are more than it! You are That!

Example 11. There was a monk who passed through a city. The king came to the monk to respect him. He kissed his feet and asked for blessing. The king said: Oh monk, I have many problems. I have enemies in my neighborhood who want to attack my city. My minister is not very productive and does not know his job. Our financial status is also not good because of the problems of city. The monk said: Oh king, this too shall pass! Then, he left. Years later, they met again. The king said to monk: thanks a lot for your prayer. Everything got resolved; my neighbors are our friends now. I changed my minister and he is good. We are also rich now. The monk said again: Oh king, this too shall pass!

The important message of this example is "this too shall pass". This sentence holds for both sadness and happiness. When facing difficulty, human should not get angry or sad as it shall pass. Also, when something good happens, human should not gain ego for that as it shall pass, too. Note that this sentence is more related to Buddhism. Hinduism goes further than it and says that "nothing even happened!" because it does not exist.

Example 12. Someone is sleeping and in his sleep, he dreams that he has won one million dollars. When he wakes up, does he go to bank and claim his prize? Of course not as he knows this never happened and that was just a dream. So is this world and nothing happens and it is just an appearance, whether sweat or sad.

Example 13. Someone was complaining a lot about his problems to a monk. After a long talk that he had, the answer of monk to him was only one sentence: "I am not interested in your problems; I am interested in you”.

In Hinduism, mind and consciousness are different. Mind is the appearance which is in body and we think it exists because of ignorance and foolishness. Consciousness is actually you or Brahman. You are not your mind but you are That. You are the consciousness which is the one who only exists and that is Brahman.

People are usually so attached to their minds that they think this life exists. They think they are their mind but it is not correct. Only God exists and this world and minds are appearances which borrow existence from God. Gaining the knowledge of profound Hinduism is just the first step. Then, human should try to get rid of this attachment and false habit.

Example 14. There was someone at the bank of a river but facing oppositely so he could not see the river. He was digging the ground to find some drops of water! His friend said "just turn around and see the river".

Example 15. An addicted person to smoking has the knowledge that smoking is not correct and he should quit smoking. However, when he is asked why he smokes while he knows it is bad for him, he answers that it is his habit and hard to quit. Thus, having the knowledge and quitting the habit are two different things!

Getting rid of attachment to the mind is extremely hard because mind is very strong in attaching human to itself. $\mathrm{Hu}-$ 
man needs to train the mind gradually to gain its control and guide it to the profound knowledge of intellect.

Example 16. Mind is like an elephant which is wild and goes everywhere it wants. The intellect (see Section 5.4.3) is like an elephant rider. At first, the elephant does whatever it wants and goes wherever it wants without listening to the elephant rider. For example, it goes to a banana tree whenever it wants. When someone wants to talk logically about profound concepts, they should not talk to the elephant as it does not understand; but they should talk to the elephant rider. Similarly, teaching of profound Hinduism should be thought about by the intellect (one's very self) and not the mind. The elephant rider should train the elephant to listen to him. If the elephant rider is lazy, he will not train the elephant and will pretend to like whatever the wild elephant does. Likewise, if someone is so attached to his mind, he may convince himself to do and like whatever his mind requests.

Example 17. After enlightenment, human sees everyone and everything as God so he loves everyone as himself because everyone is nothing but God and the separation of people is because of ignorance. This also prohibits him from gossiping as that would be talking bad about God. Moreover, he does not gain ego because he knows that separation of people is wrong and everyone is the same and should be loved.

\subsection{Does It Cause Laziness?}

A question is raised: does this knowledge that the world is not real and just an appearance cause laziness because one may think why he should try for working and doing jobs for nothing. The answer is no, it does not cause laziness. The human nature tends the human to work and try. Therefore, human tries to do tasks for the whole which is the consciousness. One of the well-known examples is Mahatma Gandhi (1869-1948) who had the profound knowledge of Hinduism (Datta, 1953) and did a lot of effort in his blessed life (Fischer \& De Kock, 1951). This is a counterexample for the doubt whether this knowledge causes laziness. A similar line of thought to this discussion is in the stoicism philosophy.

\subsection{Science Backing Up the Illusory World Theory in Hinduism}

According to string theory or $\mathrm{M}$ theory in physics (Morozov, 1992), the universe can be explained as a hologram (Talbot, 1991; McFadden \& Skenderis, 2010). According to the holography theory (Fischler \& Susskind, 1998), the universe is a hologram or projection of a two dimensional space into the three dimensional space (Susskind, 1995). In other words, the three dimensional world which we see is illusory. Recently, computer simulations and mathematics (Hanada et al., 2014; Hyakutake, 2014) have backed up this theory (Cowen, 2013). In summary, everything in the world can be modeled as an appearance or projection from some data. Hinduism has called this data God, consciousness, or Brahman. Therefore, science backs up the theory of profound Hinduism.

Moreover, Einstein's special relativity (Einstein, 1905), Einstein's general relativity (Einstein, 1915), Heisenberg's uncertainty (Schrödinger, 1930), and Gödel's incompleteness (Gödel, 1931) are also supporters of the fact that this world is illusion. Einstein has also stated "the past, present, and future are an illusion" (Isaacson, 2011). As will be explained in Section 4.7, this world is Maya and is illusion and ignorance. Hence, science has found some evidences supporting Hinduism.

\subsection{Great Sentences (Mahavakyas)}

There are four great sentences (mahavakyas) which people frame and hang in their houses. These great sentences are from the four parts of Vedas (see Section 2.1.1). These sentences are:

1. You are That!

2. I am Brahman.

3. [Your] consciousness is Brahman.

4. Jivatma is Brahman (Your very self is Brahman).

The four great sentences are saying the same thing and that is "God (Brahman) alone is, everything is not".

Note that jivatma means individual living (someone's very self) in Sanskrit. As was explained, Hinduism starts with jivatma and proves that there is no jivatma and that is merely appearance. It says that there is only Brahman and thus we understand that "Jivatma is Brahman".

There are some more great sentences, although they are not categorized as mahavakyas:

- The truth is one but the wise call it in different ways.

- Nothing can even scratch the surface of who you are.

- God alone is, everything is not.

- There is only one without the second.

- You are at the bank of a river, facing oppositely, and digging the ground for some drops of water!

- You are the ocean and this world appears to be a wave on this ocean.

- The person cannot be freed, but you can be freed from the person.

- Do not say you and me. The separation of us is wrong and because of ignorance. We are one and that one is the only one who is God (consciousness).

- A pure mind will automatically move toward God.

\subsection{The Four Levels of Truth, Maya, and Consciousness}

Hinduism categorizes truth to four levels (Puligandla, 1975):

1. Asatyam: the first level of truth which is wrong. It can never happen in reality. Examples are coolness of fire 
and a horn for tortoise.

2. Pratibhasika: the second level of truth which is the illusory reality. Dreams and mirage are in this level of truth. It is the dream state. In this level, you cannot say that it is wrong but it does not exist in reality. For example, if someone says there is a mirage there, it is not wrong but there is no water there. Another example is that someone mistakenly sees a rope as a snake.

3. Vyavaharika: the third level of truth which is the relative reality. It is the world in the waking state. Most often, we consider this level of truth to be true. Everything in this world, objects, beings, mind, and people are in this level of truth. The simplistic Hinduism, gods, humans, heavens, hells, and reincarnation are in this level of truth.

4. Paramatika: the fourth level of truth which is the absolute truth. It is the only existing truth in reality. The profound Hinduism, which states God alone is and everything is not, is in this level of truth.

Note that the second and third levels of truth are for the sake of explanation. We start with these levels which is what we normally think is true and then develop to get to the fourth level of truth. When we understand the fourth level of truth, the other levels of truth lose their validity. That is why Hinduism starts with simplistic Hinduism for public and children and builds on that to get to the profound Hinduism eventually.

All levels of truth except the Paramatika level are named Maya in Hinduism. Maya is basically about what we can observe by eyes or in dreams. The Paramatika level, however, is named consciousness which is the only real truth. Maya, which is merely an illusion and because of ignorance, is a very complicated concept so the monks teach it to very few well-deserved people who can tolerate that complexity.

Example 18. There were four Buddhists with different levels of knowledge and enlightenment. They saw a windmill which was turning with wind. The first person, with lowest knowledge, said: the windmill is moving. The second one, with slightly more knowledge, said: no, it is the wind which is moving. The third person, with more knowledge, said: no, you are wrong. It is the mind which is moving! The last one, who had the most knowledge, said: you are all wrong. Only the tongue is moving (meaning that you are just talking and there is nothing moving).

\subsection{Answer to the Hard Problems of Science}

There is a nice phrase that: "science without religion is lame, religion without science is blind" (Einstein, 1940). There are some problems in science which are considered to be very hard. Hinduism can answer these questions. In the following, we discuss some of these problems and answers of Hinduism.

\subsubsection{The Hard Problem of Consciousness}

The hard problem of consciousness (Chalmers, 1995; 2007) is the wonder how the consciousness has been developed out of matter during the evolution (Mayr, 1963). The complexity of this problem is that the matter itself is not conscious so how a non-conscious entity has caused consciousness. In other words, how matter and consciousness are related (Churchland, 2013)? Many researchers have tried to address and solve it such as (Libet, 1996; Gray, 2004). Hinduism can address this problem (Hari, 2015). As was explained in Section 4.2.3, Hinduism believes that everything is the consciousness. Therefore, the hard problem of consciousness is resolved as matter is consciousness and not its cause.

\subsubsection{Does Human Have Free Will?}

Free will (Van Inwagen, 1983) is a mysterious problem in philosophy where the question is whether human has free will or not (Libet, 1999). Hinduism can address this problem (Bronkhorst, 2012). As was explained in Section 4.2.4 and will be more discussed in Section 5.4.1, "I" in every being is not the mind but is the consciousness above the mind. Science faces the problem of free will because it considers "I" as the mind; however, Hinduism sees everything as a unique consciousness. Therefore, in Hinduism, the problem of free will is not even raised as will is in the level of mind and not consciousness.

\subsubsection{How Universe StaRted?}

How universe was started is also a hard problem in science because:

1. If it is assumed that this world was created out of nothing, then how everything is caused by nothing?

2. If it is assumed that there was something, like some energy, in the first place before creation of the world (e.g., see the big bang theory (Hawking, 2009)), then where did that initial thing come from or what caused that thing?

Hinduism criticises this problem by saying that in this question, an assumption is made and that is the existence of the world. How do you know that the world exists and you ask this question. It says it must be first proved that the world exists and then this question is valid. As was explained in Section 4.2.3, the world (matter) does not exist and only consciousness exists. Therefore, this problem is not even valid to be raised. Note that in profound Hinduism, there is no start of the world but there is an end to the world. The end is not the apocalypse as the apocalypse is just the end of a world for the world to restart (see Section 3.6). The end of the world is for every person and that is when he truly understands, in both theory and practice, that God alone is and everything is not. Note that Hinduism is a very personal religion so it defines the end of the world as the freedom of every single person. 


\section{The Four Paths in Hinduism}

Hinduism includes four main paths which are path of knowledge, path of love, path of work, and path of mind (Klostermaier, 2007). Apparently, these paths have different approaches but they seek the same goal and at the end, they all reach the same aim. They all follow Vedas; they interpret Vedas differently at first and finally they come up with the same meaning. In the following, we explain these four paths in detail.

\subsection{Path of Knowledge}

Logic is one of the essential fields of philosophy (Quine, 1986). The path of knowledge is based on the knowledge and logic (Vidyabhusana, 1988). It assumes nothing at the first (see Section 9.2.2) and tries to build the knowledge using logical explanations. It also uses many examples in its explanation for better clarification. Most of the logical explanations in Section 4 were derived from the path of knowledge. The connections to philosophy of great philosophers which were explained validates the fact that path of knowledge has a logical and philosophical background.

In the path of knowledge, human is not told to "believe" in God. The logical phrases are explained to him and he finally gains the knowledge that everything is the God or consciousness. The fact that there is no need to believe in God at the start of the path has misled some researchers to categorize Hinduism as an atheist sect (Herman, 1989), although it is not a correct categorization.

\subsection{Path of Love (Devotion)}

In the path of love or devotion, human "believes" in a God and devotes self to God. He is told that there exists a God, which is Brahman or consciousness and he should love Him by all his heart. This path has a mystical point of view which involves true love without expectation (Dasgupta, 1983). In this path, human learns that he is loved and lovable (Chopra, 2007). Moreover, he learns to love God and therefore everyone and everything because, as we discussed in Section 4.2.3, everything is God or consciousness.

A person who is in the path of love always does good things because he loves other people. He tries to benefit the society and propagate this love and happiness to others. People who are in this path are either the people who like this path the most and try to love everyone or the people who do not have a significant level of knowledge because the profound logic in the path of knowledge is difficult for them to understand. The latter group may include very young children who are taught to "believe" in God at first so they become ready for understanding the philosophy of Hinduism later when they grow up. In the path of love, human "beilives" in God without the need to know the reason of God.
Example 19. Someone believes that the sun rotates around the earth because he sees that the sun rises and sets in east and west, respectively. Although this is not completely true but it does not harm his life and the effect is similar for him.

Example 20. When a child breaks his toy, he cries because he does not have the knowledge that this toy is not very important. His mother has the knowledge and thus calms him down. When the child grows up, his knowledge gets complete and understand why his mother calmed him down.

When a person in the path of love prays to God (e.g., in a temple), he feels like a child where God is like his mother who loves him. In Hinduism, the person does not request anything from God but prayers are dedication of love to God and worshipping Him. The love of God transcends to the person. Moreover, requests and sadness of the prayer are understood by God without the prayer talking about them. Worshipping God and loving Him comports the prayer.

Example 21. When a child goes to his mother, he loves his mother and the mother loves him. He does not need to say his requests to his mother as his mother understands them without saying anything. The mother understands the problems of the child without a single word, comforts the child, and gives the child peace.

Example 22. Consider the relationship of ocean and wave. The ocean transcends the wave.

\subsection{Path of Work (Karma)}

The path of work, also called the path of karma, is based on karma (Sharma, 1973). Karma was introduced in Section 3.7. A person who is in the path of karma tries to do good things without collecting any karma. In other words, he tries to do good things without gaining any benefit from them and tries to avoid doing bad things. He will not harm anybody or anything and tries to help and benefit others and the society. In the simplistic Hinduism approach, he will rescue from the life cycles without collecting any karma. However, in the profound Hinduism approach, when he always does good things without any karma, he will finally gain the knowledge that there exists only God and nothing else and he is doing the good things for the only existing good.

The person in the path of work should work for the sake of work and should never seek or even think about the reward. He should do good works and avoid bad works because good and bad works are toward and against the eventual salvation or knowledge of profound Hinduism, respectively. Ignorance is caused by bad karma. The person does the good work because nature pushes him to work and he is willing to work by nature. People usually work much more than they need because of their nature. Path of work says let us use this willingness to work for gaining salvation and reaching the profound knowledge of "you are That". The 
person in the path of work is not attached to the reward of work and tries to do his best in his duties and good works as much as he can. If he successes or fails, he does not care.

Example 23. Consider a person who works hard in a company and wishes to become the manager of company. Although he works hard, the company does not promote him. He gets very angry. The mistake is his because he has attached himself to the reward of his work so he gets sad if he does not gain the reward.

\subsection{Path of Mind (Meditation)}

It is a well known phrase that "you are what you think" (Stoop, 2003). The path of mind, also called the path of meditation, has a similar idea. The concentration of path of mind might be less on God; this path alone may have an agnostic approach.

\subsubsection{PARTS OF A LIVING BEING}

A living being contains three parts:

1. physical body: the physical body is the "flesh" which is not living; it is an object. For example, when we see something, the eye itself does not see.

2. subtle body (Syman, 2010): the subtle body is the "mind" or "brain" which is living and understanding. For example, when we see something, the brain or mind processes the visual signals from the eye.

3. reflected consciousness: although science usually stops at the level of subtle body or mind, Hinduism goes further and also considers consciousness. In Section 4.2.4, we discussed about the dream and why consciousness exists and why everything is consciousness.

The non-living objects such as stone have merely the physical body. Plants are not considered as living beings without well-developed subtle body; thus, eating them is not a bad attitude. The humans and animals have the physical and subtle bodies.

The above categorization can be with more details. According to the Taittiriya Upanishad, there are five bodies for a being:

1. anna-maya (physical body): the physical body which is born and dies on the earth and in heavens and hells during the reincarnation.

2. prana-maya (vital breath): the breath which the lungs in the physical body have. This body is a symbol for the life of physical body. Sometimes, this body is included in either anna-maya or mano-maya in categorizations.

3. mano-maya: includes mind, memory, and intellect. We will explain it later in Section 5.4.3.

4. vijnana-maya (reflected consciousness): consciousness associated with mind. The mind reflects the true consciousness and human can feel the consciousness.
The quality of mind determines the amount of reflection like a mirror.

5. ananda-maya (reflected bliss): Bliss is the intrinsic characteristic of Brahman or consciousness. Human can reflect this bliss and feel happiness like sprays of sea on the face at beach.

Note that the subtle body includes the mano-maya, vijnanamaya, and ananda-maya. The physical and subtle bodies are Maya while Brahman is consciousness (see Section 4.7); therefore, the physical and subtle bodies are not in the fourth level of truth so they are not existing in reality. That is why an enlightened human understands that this world and this body are not and God only is.

The consciousness has two intrinsic properties:

1. Existence

2. Bliss (highest happiness)

According to Section 4.2.4, there is nothing but consciousness, i.e., God. Everything in this world is just an appearance and this appearance is borrowing its existence from the consciousness. We also saw in Section 4.3 that we should not be sad. Even when our appeared body is happy, it seems to borrow the bliss from the consciousness.

Example 24. When someone is sitting on the beach, he fills the sprays of sea on his face. Borrowing the bliss is like sprays from the ocean of consciousness.

\subsubsection{STATES OF Mind}

The mind or subtle body has one of these three states at a time:

1. sattva: good quality of mind, calmness, relaxed, and under control. This is the best state of mind.

2. rajas: having passion, greed, anger, or anxiety.

3. tamas: a lazy state. For example, sometimes, someone does not want to do anything and cannot think to anything. His mind is tired and lazy at that time.

\subsubsection{Cosmic Mind and Categories of Subtle BODY}

There exists a cosmic mind which has a tabular structure where every cell of the table is assigned to the subtle body (including mind) of a living being. The distances of cells is directly relative to the physical distance of beings. In other words, the closer beings in the physical space have closer cells (subtle bodies) in this cosmic mind. Note that the cells reorder all the time based on the movement of beings. As mentioned in Section 3.8, the heavens and hells have physical distances from the earth so the souls in the heavens and hells each also have a cell in the cosmic mind table. Moreover, as the animals also have subtle bodies, they also have cells in the cosmic mind table.

The mano-maya of a living body, introduced in Section 5.4.1, includes six parts:

1. mind: this can process the understanding, feeling, see- 
ing, and processing the world. Both animals and humans have minds.

2. knowledge: this is gained by studying and practicing.

3. intelligence (intellect): this is the ability to learn and produce.

4. memory: this is the ability to memorize, remember, and recall. Note that science considers memory as a part of brain which is in the physical body; however, Hinduism considers memory in the subtle body which never dies and is with human in incarnations. That is why some people remember their previous lives.

5. personality: this is how a being behaves and reacts to different situations.

6. connection to the cosmic mind (telepathy): this is a very high technical ability and means connection to the other minds (cells) in the cosmic mind table. This is also referred to as telepathy (Derrida, 1988).

Note that the subtle body, although does not exist according to the profound Hinduism, never dies and is the human who goes through incarnation. Therefore, if someone is good in something, e.g., math, it means that he has practiced math in his previous lives. Hinduism does not believe in talent but it believes that people practice skills in their lives.

Example 25. Consider a person who has several jobs. Sometimes he is a cook, sometimes a policeman, and sometimes a guard. In every job, he wears a special uniform. He is the same person but wears different cloths. So is the subtle body which is the same during the reincarnation and the physical bodies in different lives are like the uniforms which the subtle body wears.

The levels of the mentioned categories are different in different beings, especially there is a huge difference between human and animals. Mind exists in both animals and humans; however, the other categories are often less in animals compared to humans.

Here, we explain more about connection to the cosmic mind. everybody's mind is connected to the cosmic mind but some people have this ability to focus on this connection because they have practiced it and they have a very strong mind. They can connect to the minds of other people and either other animals. Hence, they can read others' minds, their questions, and their thoughts. They can also communicate with others through the cosmic mind so they can answer the questions without talking. Many monks do have this ability. People go to the temples and stand in front of a monk and get their answers without saying a single word.

Connecting to other minds through the cosmic mind is easier when the minds are closer in the cosmic mind table. Therefore, when two beings are closer to one another in terms of physical distance, they can have a stronger telepathy. That is why people go to temple and stand in front of the monk for getting their answers. Note that very powerful minds can even connect to the minds of souls in the heavens and hells which are far away from the earth (Werner, 2008).

\subsubsection{FocUs AND MEDITATION}

The subtle body is the channel and flow of energy (Samuel, 1989). Therefore, one can focus his mind deeply on the truth and try to leave all the distractions in his thoughts. This is also referred to as meditation (Moore, 2008) where the mind is focused and not distracted. One of the methods for meditation is yoga (Phillips, 2009) which is also well-known by the non-Indians. It is noteworthy that the word "Namaste" which is used frequently in modern yoga meditations is the word "hello" in Sanskrit. Moreover, in some of the similar approaches of meditation, deep focus is referred to as Zen (Humphreys, 1949).

Meditation helps the human focus on the truth. When someone reaches the truth by concentration, he gains the profound knowledge of Hinduism that everything is consciousness. Hence, the ultimate goal of meditation is to reach this knowledge and truth.

Example 26. There was a Buddhist student in a temple who wanted to become enlightened. He had a teacher who told him to meditate and focus on the top of a flower. He meditated for many hours and came back happily saying to his teacher that he found the truth. His teacher told him that he has not found it. So, he meditated harder and came back shouting that he has found the truth. Again, the teacher refused it. Finally, he meditated and did not say a single word after it. Even, he did not get excited about his findings. Then, the teacher said to him: Now, you have found the truth!

Note that one way to focus deeply on the connection to the cosmic mind is to clear or empty your mind completely so that the thoughts of others get reflected to your mind. If a mind has a lot going on in it and is therefore distracted, it cannot reflect other minds; however, if the mind is empty and clear, it acts as a mirror for other minds.

Example 27. (Rumi, 2008b): There were two groups of painters who claimed to be the best in art. The king asked the groups to each paint on one of the two opposite walls in a room. There was a curtain between the two walls. The first group took a lot of paints and painted a very pretty sketch on the wall. The second group, however, just polished the wall. The king saw the painting of the first group and it was very good! But when it was the second group's turn, they dropped the curtain and the painting of the first group was reflected on their wall. They did not paint at all and just polished but the beauty of painting doubled in the reflection!

Example 28. One of the Hindu monks has said: I can teach you all the profound knowledge only in ten minutes. Just bring me a pure mind! 


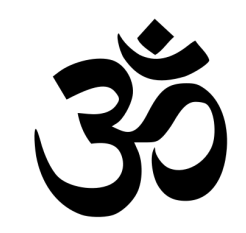

Figure 2. Aum: the symbol of Hinduism and Brahman

\subsection{5. АUM (OM)}

In very deep meditation, a sacred sound can be heard (Beck, 1995). This sound is Aum, also written as Om. In non-monism schools of Hinduism which believe in creation (see Section 6), the Aum is the sound from which all the sounds and everything are created (Kumar et al., 2010). As this sound is very sacred, Aum is considered as the best name for the God (Brahman) or consciousness. Aum also is a symbol which is the symbol of Hinduism or God. This symbol is shown in Fig. 2. It is noteworthy that chanting of Aum has been investigated to be effective for reducing anxiety and depression (Amin et al., 2016).

\subsection{All Paths Will End the Same!}

At the first glance, the four paths of Hinduism might seem different. The paths have different approaches but have the same goal ultimately. The path of knowledge starts with not believing in anything and using logic, it proves that everything is consciousness and that can be called God or Brahman. The path of love starts with loving God and loving everyone by doing favors to them. Then, the human gradually understands that he is loving everybody and everything because everybody is the God and there is nothing but God. The path of work starts with avoiding bad works, doing good things and having good attitudes without any expectation of benefit and joy. The human gradually understands that he is doing the good works because there only exists one goodness which is consciousness or God. Finally, the path of mind starts with concentration of mind on the truth and avoiding distraction. In this path, human eventually understands that there is only one truth on which he is concentrating and that one truth is God. In all paths, an enlightened human finally understands that God alone is and sees nothing but God.

\subsection{Risks for Every Path}

Every person has more talent for one of the paths. For example, if a person is more into science and logic, path of knowledge is better for him. Path of love can be better for a person who likes faith more than proofs and logic. Paths of work and mind are better for people who are more willing to seek salvation by work and meditation, respectively.

In general, it is recommended to people to follow all the paths together if possible but with some more focus on one of the paths. Although, even one of the paths suffice for a person to reach salvation and gain the knowledge of "you are That", but sticking to merely one of the paths and completely ignoring other paths may have some risks. In the following, we mention some of these risks.

\subsubsection{Risks FOR ONLY PATH OF KNOWLEDGE}

The advantage of path of knowledge is that it is based on reasoning and logic; thus, it does not easily shake during the life. This is not necessarily true for faith and path of love because one might lose their faith in any stage of life.

The risk for sticking to only path of knowledge is a possibility for the person to gain ego and become proud of himself and his knowledge. Thus, he might underestimate other people and sees them as naive.

Example 29. Al-Ghazali (Watt, 1953) was a religious leader and teacher in Islam. As he says in his autobiography (Al-Ghazali, 2000), he used to debate with many Islamic philosophers about different topics. However, suddenly, he changed and went to a long trip. Then, he went to al-Khalil where the sepulchre of Abraham is located. There, he made a promise to God not to debate again and to change his life. Later, he told his students not to seek philosophical debates because in these discussions, people will continue to defend their own opinion even if they find out that they are wrong. They do it not to be stultified; so they sacrifice the truth for their ego.

Example 30. (Attar, 2003): Bubakr al-Nishapuri was a Muslim mystic who was passing through an alley on his donkey. Many of his followers were following him in the way. Suddenly, the donkey farted loudly. Immediately after that, he exclaimed. In those days, when a mystic exclaimed because of an enlightenment, the followers used to exclaim, too. However, no one exclaimed because they were shocked. The day after, someone asked him why he exclaimed after the fart of donkey. He answered that he was thinking that he is a very holy man and he has many followers. He was in a huge ego when the donkey farted. He was enlightened that if someone gets proud of self, he/she will be answered by the worthless fart of donkey!

Example 31. When a tree gains many fruits, it bends. Likewise, humans should become more humbled when they gain more knowledge.

\subsubsection{RisKS FOR ONLY PATH OF LOVE}

The advantage of path of love is that it is the "fastest" path to reach salvation because it is based on faith and does not require one to study many books and gain deep knowledge. The possible disadvantages of path of love are:

1. It is based on faith so it may become shaky during the problems of life.

2. The person in path of love may believe that other religions are wrong and the pluralism of religions is not correct. Even if he does not say it, he may believe 
that are other beliefs are false and the people following those religions will not have salvation.

3. The person in path love should devote himself to God and love God and others without expectation. However, he may deviate from this goal and pray to God as in business and asks God for blessings. If God does not provide him the blessings, he may quit his faith in God. In other words, he might confuse love with business.

Example 32. (Rumi, 2013): Daghooghi was a mystic who was praying with some other sages. While they were praying, they saw a ship in the sea which was being drawn and the people on it were very scared. Daghooghi felt sorry for them and prayed to God to calm down the see. When the prayer was over, the sages looked at one another wondering who prayed and asked God to change the fate and God's will. When they found out it was Daghooghi, they disappeared from his sight. Rumi, the poet, says "I know a group of sages who do not pray [because they think prayer should be just for praising God and not for business]". Note that Example 21 is related to this concept, too.

\subsubsection{RISKS FOR ONLY PATH OF WORK}

Path of work concentrates on doing work for the sake of work without expecting any reward. Its advantage is that the person does his best in every good work and is not attached to its result. A possible risk in path of work is that the person gradually gets attached to the rewards of his work and says to himself that I did it, so I need to see the result. Then, if he does not see the result, he may get disappointed.

\subsubsection{RisKS FOR ONLY PATH OF MIND}

Path of mind tries to focus on mind and concentrate it toward the truth. The advantage of this path that the person practices to calm and organize his thoughts. The people in this path usually have scheduled plans for meditation and this usually becomes a habit for them. A possible disadvantage of this path is that if someone or something distracts or interferes this plan, they may get very angry because of not following the schedule.

\section{Orthodox Indian Schools in Hinduism}

There exist six Indian schools which believe in and follow Vedas. These schools are referred to as orthodox or Astika schools. The orthodox schools are Samkhya, Yoga, Nyaya, Vaisesika, Mimamsa, and Vedanta.

Adi Shankara, also known as Shankaracharya, was a great Indian philosopher and spiritual leader in the early 8th century (Menon, 2004). Before him, most of Indians were Buddhist but after his philosophical debates, most of Indians accepted Vedanta as one of the orthodox schools. He debated with many different philosophers logically and explained that the six orthodox schools which follow the Vedas are correct among the Indian schools up to that date.

\subsection{The Six Pramanas}

Before introducing the orthodox schools, we need to introduce the six Pramanas in Hinduism. There are six means of accurate knowledge and truths in Hinduism (Flood, 1996). These means, named Pramanas, are:

1. Pratyaksa (perception): it can be internal or external perception where the five senses are interacted with objects and the perception is done in mind, respectively.

2. Anumana (inference): concluding a new truth from some observations and previously proved truths.

3. Upamana (comparison and analogy): Using comparison or describing the similarities for concluding a truth.

4. Arthapatti (postulation): it is derivation from circumstances. In modern logic, it is named implication.

5. Anupalabdhi (non-perception): it is negative or cognitive proof. Knowing that something does not exist adds to the knowledge and is better than knowing nothing. For example, not seeing the fingerprints of someone on the gun of a murder resulting in their absolution.

6. Sabda: it is based on the testimony of past or present reliable experts. For example, a student trusts a teacher without asking for proof.

\subsection{Samkhya}

Samkhya (Larson, 2001) accepts Pratyaksa, Anumana, and Sabda among the Pramanas. It believes in duality where everything belongs to either Purusa (consciousness) and Prakrti (matter). A living being (called Jivan in Sanskrit) is the consciousness but bounded in the body and mind as matter. This bondage is because of imbalance or ignorance. Samkhya is closely related to the Yoga school.

\subsection{Yoga}

Yoga (Dasgupta, 2013) is an Indian school which is closely related to the Samkhya school. Similar to Samkhya, it accepts Pratyaksa, Anumana, and Sabda among the Pramanas. It also has a dualism approach with consciousness and matter. Like Samkhya, it states that the bondage of consciousness to the mind in human is because of ignorance. Human can get rid of this bondage by becoming Moksha (free) because of gaining the profound knowledge of freedom in both theory and practice.

The main difference between Yoga and Samkhya is that Yoga believes in a personal, yet essentially inactive, deity or a personal god named Ishvara. Samkhya does not concentrate on God and states that knowledge is sufficient for freedom from the bondage; however, Yoga recommends both knowledge and personal practice. 


\subsection{Nyāya}

Nyaya (Phillips, 2013) is an Indian school which is completely logic and methods. It is used in other Hinduism schools, especially in Vedanta, as a tool for proofs and philosophical discussions. One of the important axioms which Nyaya accepts as default is the following sentence: "Negation is assumed to be true until the assertion is proved". Therefore, an atheistic perspective (non-existence of God) is first assumed but it finally proves the existence of God. The reason is that atheism is not a religion or belief but is negation of belief in God.

Example 33. When I say my hobby is collecting stamps, you can ask me to prove it to you. Then, I can show you my collection of stamps as a proof. However, when I say collecting stamps is not my hobby, you cannot ask me to prove it to you because to prove it, I should show you every second of my life which is not spent on collection of stamps and that is impossible and unreasonable.

\subsection{Vaiśeșika}

Vaisesika, also called Vaisheshika, was founded by Kanada Kashyapa. Its philosophical approach is close to Nyaya. It accepts only perception and inference amongst the Pramanas. It has a naturalism approach which believes that everything is made of atoms; the atoms are neither created nor destroyed. Therefore, a physical approach it has (Narayan, 2007). It states that the four materials, i.e., earth, water, fire, and air are all made of atoms.

\subsection{Mīmāṃsāa}

The Mimamsa school (Bronkhorst, 2007) is more focused in the early Vedas and does not concentrate on Upanishads. Its main text is the Mimamsa Sutra written by rishi Jaimini in the 4th century BCE. Mimamsa worked significantly on the philosophy of language and inspired many other Indian schools such as Vedanta for using linguistics in description and deduction. Mimamsa does not focus on God but it concentrates on the dharma which is the rituals and social duties extracted from the Vedas. Mimamsa has several sub-schools, two of which are Prabhakara and Bhatta. Prabhakara accepts five Pramanas which are all Pramanas except Anupalabdhi (non-perception); however, Bhatta accepts all the six Pramanas.

\subsection{Vedānta}

As mentioned before, Vedanta, also called Uttara Mimamsa, is the heart of Hinduism (Torwesten \& Rosset, 1994) and thus most of Hindus, nowadays, follow the Vedanta school. The main texts in Vedanta school are Vedanta (Upanishads) and Bhagavad Gita from the Vedas and a developed book based on the Vedas, named Brahma Sutras (Vireswarananda, 1936) written in between 450 BCE and 200 CE. After Adi Shankara (Menon, 2004), most of Indians tended to Vedanta school. Vedanta school consists of three sub-schools, i.e., Advaita, Vishishtadvaita, and Dvaita, each having its followers.

\subsubsection{AdVAITA}

Advaita Vedanta, also called Purusavada, believes in nondualism. It believes that the very self of person, called Atman or Jivatman, is the same as the holy God, Brahman or consciousness. In other words, there is nothing but God and "You are That!". Note that there is a slight difference between soul in Abrahamic religions and Atman in Advaita. Abrahamic religions say that human has a soul but Advaita says human is nothing but Atman; the body and mind are appearance and ignorance. The profound Hinduism which was explained in this paper had the approach of Advaita which is non-dualism. Adi Shankara (Menon, 2004), who was influenced by Gaudapada in the Ajativada school (see Section 7.4), was the founder of Advaita.

As a symbol, the followers of Advaita Vedanta usually put Shaivite on their forehead. The Shaivite is the ash of fire and is white. Scientifically, this is also good for body because it absorbs heat from the forehead. The ash covers a circle or an area on the forehead.

\subsubsection{VISHISHTADVAITA}

Vishishtadvaita, which was founded by Ramanuja (Ranganathan, 2004), is a sub-school of Vedanta with qualified monism approach. It states that the Atman (soul) and God (Brahman) are different but there is a unity of all souls and every human Atman can ultimately become the servant of God in paradise (see Section 3.8).

Example 34. An example for the unity, but separation, of Atman and God qualified non-dualism is the cover of a travel mug which is connected to the mug. The cover and mug are separated but you cannot say they are different as they belong to the same mug. God and human's Atman are like the body and cover of mug, respectively.

The reason for the word "qualified" in Vishishtadvaita is that it considers three different qualities for everything:

1. Chit: living and sentient. It has consciousness.

2. Achit: nonliving and insentient. It does not have consciousness.

3. Ishvara: It has Chit and Achit as its attributes plus some other auspicious and good attributes. Examples for it are Vishnu, Shiva, and Brahma (see Section 3.1.2).

These three all together are called Brahman. Some debates between Advaita and Vishishtadvaita sub-schools can be found in (Grimes, 1990).

The symbol of followers of Vishishtadvaita on their forehead is a red vertical line and a bowl-shape white line surrounding it. For men and women, this symbol is made of herb and powder of sandal wood (bark of sandal), respec- 
tively.

\subsubsection{DVAITA}

Dvaita, founded by Madhva (Sarma, 2017), has a dualism approach. It states that the Atman (soul) and God (Brahman) are completely different and separate. God is perfect in knowledge, power, and purity and His grace is the only way for salvation of humans' souls. In Dvaita, God is considered transcendental. This is almost the approach of non-mystical perspectives in the Abrahamic religions. The symbol of the followers of Dvaita on their forehead is a yellow vertical line.

\section{Connection to Other Indian Schools}

One of the many beauties of Hinduism is that not only does not it reject other religions but also it accepts them as correct religions and categorizes them as paths of Hinduism. In India, there exist some other religions which are categorized as heterodox Indian schools in theology. The heterodox Indian schools are Buddhism, Jainism, Charvaka, and Ajativada. These religions do not believe in God and Vedas. Sikhism, however, believes in God and is not categorized as a heterodox Indian school. Although, Hinduism has some differences from these schools, e.g., in believing in God, it has many connections with them. In the following, we explain these connections and differences.

\subsection{Connection to Buddhism}

Buddhism accpets only two of the Pramanas (see Section 6.1) which are perception and inference (Bhawuk, 2011).

\subsubsection{The Four Noble Truths}

The Four Noble Truths of Buddha (Sumedho, 1992), which he found out when he was in meditation under the Bodhi tree (Herbert, 2005), are:

1. Dukkha (the truth of suffering): Buddhism says life is not ideal and suffer always exists. Even if only joy exists for someone, it will become monotonous for him.

2. Samudāya (the truth of the origin of suffering): There exist three fires or three roots of evil which cause suffering. They are greed, ignorance, and hatred. In summary, Buddha said that attachment to negative, positive, or neutral thoughts and sensations cause suffering. In one word, desire is the cause of suffering.

3. Nirodha (the truth of the cessation of suffering): In order to extinguish desire, one should liberate himself from attachment. Therefore, Buddha said that there exists a way for freeing self from suffering.

4. Magga (the truth of the path to the cessation of suffering): Buddha prescribed an eight-fold path for liberating from suffer:

(a) Right understanding: understanding Buddha's teachings by thinking to them and not just imitating. Buddha asked his followers to think about his teachings and do not accept them blindly.

(b) Right intention: commitment to having good attitudes.

(c) Right action: Behaving peacefully and having good attitudes.

(d) Right livelihood: avoiding bad attitudes.

(e) Right effort: practicing positive states of mind and avoiding evil and negative thoughts.

(f) Right mindfulness: developing awareness of body and mind.

(g) Right concentration: focusing mind and avoiding mental distraction.

The item of right understanding is a connection to the path of knowledge in Hinduism. The items of right intention, right action, and right livelihood have connections to the path of work (karma) in Hinduism. The items of right effort, right mindfulness, and right concentration have connections to the path of mind (meditation) in Hinduism.

\subsubsection{PURNA VERSUS SUNYATA}

Buddhism finally comes up with voidness, nothingness, or emptiness after cessation of suffering (Cioran \& Brown, 1970). It states that "void, void, everything is void". The voidness in Buddhism is called Sunyata (Dallmayr, 1992). In other words, Buddhism starts with the fact that there exists suffer and then it finds out that there is a solution for cessation of suffering. Then, it finds solutions for this release. Finally, it finds out that there is nothing and everything is void. Thus, it falsifies that there exists suffer in the first place.

Hinduism, however, finally finds out that there is only one thing and that is God. The fact that everything is God or Brahman or consciousness is called Purna, also written as Prajñā, which means everything. Therefore, the conclusion of Hinduism, i.e., everything is one thing and that is God (or consciousness), is opposite to the conclusion of Buddhism, i.e., there is nothing (Ichimura, 2001). Except this concept of God and monism, Hinduism accepts the Buddhism approach.

It is noteworthy that Hinduism and Buddhism are basically saying the same thing. Hinduism says that everything is the same thing and that is God. Hence, God is believed to be infinity in Hinduism. Buddhism, however, considers God to be nothing (Hence, does not believe in any God). In other words, God can be considered to be zero in Buddhism. In mathematics, zero and infinity can be considered the same thing because when infinity overflows (such as in a computer), it becomes zero. With this analysis, it can be said that the ultimate knowledge of truth is somehow the same in Hinduism and Buddhism.

Example 35. (Landaw, 2011): In ancient India, there was prince named Siddhartha. He was forecast to become ei- 
ther a great emperor or a monk. After observing the suffers of people, he left the palace and sought the true enlightenment. He tried different ways such as an approach where people eat very small food. He was very weak and once he was passing a river, he felt extremely tired. He came out of river very hard and sat under a tree deciding that he will either die here or find the truth. He meditated and finally got enlightened. He found out that the truth is so simple and that is there is no truth. The way to escape suffering is to understand that there is nothing to seek. Whatever you seek is inside you (this is also what mysticism and Sufism find at their last step where the seeker gets one with the goal).

\subsubsection{REINCARNATION AND MOKSHA VERSUS NIRVANA}

In Hinduism, when someone gains the knowledge of Purna, he is called moksha, or jivan mukta, or mukta, which means "free while living". In Buddhism, the one who gains the knowledge of Sunyata is known to have reached nirvana. Therefore, moksha and the one having nirvana are enlightened to the knowledge that everything is consciousness and there is nothing, respectively. Note that the enlightened person to nirvana is also called a Buddha.

The concept of reincarnation has some differences between Hinduism and Buddhism. In Hinduism, a person who has not yet been enlightened to be jivan mukta goes to a heaven or hell after his death, depending on whether he has good or bad karma. After his karma is cleared in heaven or hell, he is reborn on the earth. When a person becomes jivan mukta (and thus does not have any karma), he goes to paradise after his death and remains there forever. However, in Buddhism, the person who has not gained nirvana is reborn directly on the earth after his death. Therefore, there is no heaven or hell between two successive lives of a person. When a person gains nirvana, he goes to a paradise with eternity after his death. Hence, release from the cycles of reincarnation because of the enlightenment is similar in Hinduism and Buddhism.

\subsubsection{OPTIMISM VERSUS PESSIMISM OR REALISM}

As Buddhism starts with identifying suffer and tries to find out a solution for releasing from it, it is sometimes called to be pessimistic. However, Buddhism calls itself realistic because they see the non-ideal life and try to find a solution for it and not remaining in the suffer. On the other hand, Hinduism may be considered to be optimistic because it finally finds out that everything is the only existing goodness which is the consciousness or God.

\subsection{Connection to Jainism}

Jainism was founded by an ancient Indian spiritual leader named Mahavira, also known as Vardhamana (Law, 1937).

\subsubsection{THE FIVE Vows}

In Jainism (Von Glasenapp, 1999), one should avoid all violent activities which put the person away from salvation. There exist five vows for people to make:

1. Non-violence (ahimsa): people should not harm or kill any being. They also should not encourage or cause others to harm or kill a being. Killing and harming beings result in bad karma.

2. truth (satya): people should always speak the truth and they should not encourage anybody to lie.

3. not stealing (asteya): people should never steal from one another. They should ask for permission if they want to deal with something which is not theirs.

4. celibacy (brahmacharya): it is recommended to the monks to avoid sex and sensual pleasures. For the regular people, this item means loyalty to their own partner.

5. Non-attachment (aparigraha): people should avoid attachments to and possessions of any property including both the material and the psychic.

The vows for non-violence, truth, not stealing, and celibacy can be considered to have connection to the path of work in Hinduism because of avoiding bad attitudes. The vow for non-violence is also related to the path of love in Hinduism as it avoids harming others because of the love to them. The vow for non-attachment can be considered as the goal and conclusion of Hinduism as it finally states that everything is the consciousness so human should not have any attachment to this world which is merely an appearance (see Section 4.3).

\subsubsection{MANY-SIDED REALITY (ANEKĀNTAVĀDA)}

One of the beauties of Jainism is the concept of many-sided reality or anekāntavāda (Dundas, 2003). It states that the reality is too much complicated to be able to explain it in words. Therefore, language can never explain the truth as a whole and thus every description of the truth is a partial explanation. Jainism says one should accept the phrases "it is" and "it is not" with the word "perhaps". This concept has a slight connection to the path of knowledge in Hinduism as it is related to reasoning and philosophy of logic (Quine, 1986).

\subsubsection{GOD AND CREATION IN JAINISM}

Jainism says that the world was never created and it will never end. The world is independent and does not need to have any creator or judge (Von Glasenapp, 1999). Therefore, Jainism does not believe in any God or gods. In terms of having God, it defers from Hinduism but in terms of saying that the world never is created nor will end, it has some connections to Hinduism. Hinduism believes that there is no world to have creation or end (see Section 4.8.3) and Jainism says the same while believing in existence of the world. 


\subsection{Connection to Charvaka}

Charvaka (Acharya, 1978) is one of the philosophical approaches in the Hindu philosophy (Shastri, 1967). It is extinct now but its origin goes back to either $1500 \mathrm{BCE}$ in works of Brihaspati or $600 \mathrm{BCE}$ in works of Ajita Kesakambali, at the time when Buddhism and Jainism were competing philosophically. Ajita Kesakambali was an Indian philosopher. The book of Charvaka is Barhaspatya Sutras, also called Lokayata Sutras.

Charvaka is the Indian materialism which believes that everything which is perceived by observation is true and all the inference is prone to be wrong and conditional. It claims that the inference that we have from observations can be wrong because we can never test all the possible cases. For example, if we see smoke, we cannot conclude there is fire there because something else might have caused it. Hinduism falsifies this claim of Charvaka because Charvaka is making an assumption that observation is true; why this assumption should be true? As Charvaka tries to discuss the logic and inference, it can be slightly related to the path of knowledge in Hinduism although it is making wrong assumptions accroding to Hinduism.

\subsection{Connection to Ajativada}

Ajativada was founded by Gaudapada who was inspired by the philosophy in Madhyamaka Buddhism. Adi Shankara (Menon, 2004), who founded the profound concepts of Advaita Vedanta (see Section 6.7), was significantly inspired by Ajativada philosophy and named Gaudapada the great teacher (Potter, 1970). Gaudapada himself was inspired by the Mandukya Upanishad (see Section 2.1.2).

Ajativada states that the absolute is the Aja which means unborn eternal. Everything else is appearance or Maya, the concept which was used later in Advaita Vedanta. The term Ajativada means the doctrine of non-origination. It states that the non-originated eternity which is named Brahman never was born, never dies, and never changes. The nondualism approach in Advaita Vedanta has taken the basis of its philosophy from Ajativada.

\subsection{Connection to Ajnana}

Ajnana is the extinct Indian philosophy which had a skepticism approach (Barua, 1970). It questions everything and the knowledge itself without providing any self doctrine. It states that the knowledge and inference may be wrong and are conditional; in this sense, it is a radical form of Jainism and Chavarka in terms of skepticism. It also states that even if knowledge is correct, it is not useful for insight and reaching the truth. Hinduism has falsified it because it is based on knowledge and logic (see Section 5.1); however, in terms of questioning this world as an illusion, Hinduism may have some connections to Ajnana.

\subsection{Connection to Sikhism}

Sikhism (McLeod, 2009) is one of the most recent religions which was founded by Guru Nanak in the 15th century in Punjab located at the north India. Its holy book is Guru Granth Sahib. Sikhism believes in one almighty God named Ik Onkar. Thus, it is a monotheistic religion, even categorized as a monistic and panentheistic religion by some scholars (Singh, 1990). It states that human should establish union with God, know His will, and carry out that will (Marwaha, 2006). Sikhism describes God as timeless, spaceless, and formless. The Sikhs cover their head with a hat named turban or dastar because the head is the closest body organ to the sky where the holy God has kingdom; thus, it should be covered for respecting God. In terms of believing in one God and monism, there is a strong connection between Sikhism and Hinduism.

\section{Connection to Some Other Religions}

As was mentioned before, one of the beauties of Hinduism is that it does not reject other religions but it accepts them as correct religions and categorizes them as paths of Hinduism. It believes that all the holly religions are correct. This is also referred to as pluralism of religions (Giordan \& Pace, 2014). In Section 4.6, we mentioned that Hinduism says "the truth is one but the wise call it in different ways".

Example 36. (Deshpande, 1958): Mahatma Gandhi said: "I believe in the fundamental truth of all great religions of the world. And I believe that if only we could, all of us, read the scriptures of the different faiths from the stand-point of the followers of those faiths, we should find that they were at the bottom, all one and were all helpful to one another." He also said: "Belief in one God is the cornerstone of all religions. But I do not foresee a time when there would be only one religion on earth in practice. In theory, since there is one God, there can be only one religion."

There are many connections between Hinduism and other religions. Here, we explain the connection to some other religions, i.e., Judaism, Christianity, Islam, Islamic mysticism, and Zoroastrianism. The holy people and prophets in the religions are Saguna Brahman or Ishwara (incarnations of God) who understand God better and try to explain Him to other people. For example, in Judaism, Christianity, Islam, Islamic mysticism, and Zoroastrianism, Hinduism considers Moses, Jesus, Muhammad, and Zoroaster as Saguna Brahman.

Different religions concentrate on different paths but they may have some portions of all the paths. Hinduism is a selfinquiry religion which focuses on every single person and says that "you are That!"; however, Abrahamic religions are God-centered and mostly based on faith. Therefore, in general, the Abrahamic religions may be categorized as the path of love. These religions also have connections to other paths which are explained in the following. 
Here, we provide two interesting illustrations for pluralism of religions (Arberry, 2013):

Example 37. (Rumi, 2013): Some people entered to a dark room. An elephant was in the room but the people did not know what it is. Someone touched the trunk of elephant and said it must be a pipe. Someone else touched its leg and said it must be a column for the room. Another one touched the back of elephant and said it must be a bed. All were judging according to their experience but they were all talking about one thing which was elephant!

Example 38. (Rumi, 2008a): There were four Persian, Turk, Arab, and Roman people who had some shared money. The Persian said he wants to buy "angoor". The Turk rejected and said they should buy "uzum". The Arab and Roman, however, said they want "anab" and "stafili", respectively. They were fighting until someone told them that all angoor, uzum, anab, and stafili mean grapes in different languages. They were saying the same thing but with different languages!

\subsection{Connection to Judaism}

In Bible (Bible, 1984), books of Leviticus and Deuteronomy contain many Jewish rules about the style of life, what to eat, how to behave, how to sacrifice for God, etc. The Ten Commandments (Harrelson, 1997), mentioned in the books of Exodus and Deuteronomy in Torah (Mann, 2013), are the ten rules for having good attitudes and avoiding bad attitudes. These show the connection of Judaism to the path of work (karma) in Hinduism.

Moreover, in the burning bush, God said to Moses: "I am who I am" (see Bible, book Exodus 3:14). This means that God never dies and is never created or born. Hinduism also says that there is not creation or death for Brahman. Brahman only is and always has been.

Example 39. Bible (Bible, 1984), book of Daniel, chapters 4 to 6, the story of Daniel in the lions' den: Daniel was very dear to the king Darius the Mede. Some people in the palace, who were jealous of Daniel, tricked the king to give an order that whoever worships anyone except Darius will be condemned to death in the lions' den. After this order, they said to the king that Daniel prayed to God. Hence, the king sent Daniel to the den although he did not want to. The lions were extremely hungry but they were very calm and did not hurt Daniel at all. This miracle may be explained by communication of Daniel and lions through the cosmic mind (see Section 5.4.3) because of the holy and powerful mind of Daniel. The king, then, sent those jealous people to the den and they were torn up by the lions at the first second of entrance to the den. This shows a connection to the path of mind in Hinduism.

Example 40. Bible (Bible, 1984), book of Daniel, chapter 2, the story of Daniel interpreting a dream: The king of Babylon, Nebuchadnezzar II, had a dream in his sleep and asked for its interpretation without telling his dream to anybody. His dream was about a statue with head of gold, arms and chest of silver, belly and thighs of bronze, legs of iron, and feet of mingled iron and clay. Daniel, without asking the king about what the dream is, explained the dream to the king and interpreted it. He said that the statue is a symbol for his and his descendant's kingdoms. The holy and powerful mind of Daniel could read the mind of Nebuchadnezzar to find out his dream. This shows the connection to the path of mind in Hinduism.

Moreover, in Bible (Bible, 1984), Leviticus 19:18, God says: "Do not seek revenge or bear a grudge against anyone among your people, but love your neighbor as yourself. I am the Lord." Therefore, Judaism may also be considered as path of love. This aspect is stronger in Christianity as we will explain in the next section.

\subsection{Connection to Christianity}

In Bible (Bible, 1984), Luke 10:27, there is a conversation between someone and Jesus: "He answered: Love the Lord your God with all your heart and with all your soul and with all your strength and with all your mind; and, Love your neighbor as yourself." Also, in Bible (Bible, 1984), John 4:8, John 4:12, and John 4:16, we, respectively, see: "Whoever does not love does not know God, because God is love.", "No one has ever seen God; but if we love one another, God lives in us and his love is made complete in us.", and "And so we know and rely on the love God has for us. God is love. Whoever lives in love lives in God, and God in them." In Bible, John 3:16, we also read: "For God so loved the world that he gave his one and only Son [Jesus], that whoever believes in him shall not perish but have eternal life." These clearly show the connection of Christianity and the path of love in Hinduism. Moreover, loving neighbor as self in Christianity has connection to Example 17.

Christianity puts more emphasise on path of love than path of work which is more focused in Judaism. In Bible (Bible, 1984), Mark 12:33, we read: “To love Him (God) with all your heart, with all your understanding and with all your strength, and to love your neighbor as yourself is more important than all burnt offerings and sacrifices." Also, in Bible, Matthew 12:9-11, we also read "Going on from that place, he [Jesus] went into their synagogue, and a man with a shriveled hand was there. Looking for a reason to bring charges against Jesus, they asked him: Is it lawful to heal on the Sabbath? He said to them: If any of you has a sheep and it falls into a pit on the Sabbath, will you not take hold of it and lift it out?"

Moreover, in Bible (Bible, 1984), John 14:10, Jesus says: "Don't you believe that I am in the Father, and that the Father is in me? The words I say to you I do not speak on my own authority. Rather, it is the Father, living in me, 
who is doing his work." Note that Father refers to God in Christianity. This, the whole book of John in Bible (Countryman, 1987), and the concept of Holy Spirit (Sproul, 1994) clearly show a mystical point of view in Christianity (Soltes, 2009); therefore, there is a connection to the concept of monism and pantheism in Hinduism.

\subsection{Connection to Islam}

In Quran (Pickthall, 1973), chapter al-Zelzelat, verses 7 and 8, we read: "Whoever does a bit good job will see its reward and whoever does a bit bad job will see its reward". Therefore, Islam considers good and bad karma for humans, although its definition of karma is a little different. In Islam and mostly in Abrahamic religions, good karma is considered to be a good thing while having no karma is ideal in Hinduism. Note that in Abrahamic religions, showing off the good karma reduces from the karma and it is recommended not to show off the good work (e.g., see Bible (Bible, 1984), Matthew 6:3, where Jesus says "But when you give to the needy, do not let your left hand know what your right hand is doing"). In Islam, the good karma is called sawab. Because of the good karma (sawab) and bad karma and also the regular prayers in Islam, it is connected to the path of work in Hinduism.

Moreover, Quran (Pickthall, 1973), chapter Ghalam, verse one, says: "Swearing to pen and to whatever is written". Also, Muhammad said:

- "Seek the science even if it is in China [which is very far]; the request for knowledge is an obligation on every Muslim" (see Maniat-ol-Morid, Shahid Sani).

- "Seek the science since cradle until sepulchre" (see Nahj-ol-Fasahat, Hadith 327).

- "To me, the blessing of science is above the blessing of worship" (see Tohaf-ol-Oghul, Hadith 41).

- "Science is better than worship" (see Kanz-ol-Ommal, Hadith 28657).

- "A bit of science is better than a lot of worship" (see Maniat-ol-Morid, Hadith 105).

- "To God, gaining knowledge is better than praying, fasting, pilgrimage, and jihad" (see Kanz-ol-Ommal, Hadith 28655).

Thus, Islam puts a significant importance to knowledge and science. This is the reason for why science improved a lot in Islam and the middle east in Islam's golden age (Nasr \& De Santillana, 1968). In this sense, Islam also has connection to the path of knowledge in Hinduism.

In Quran, chapter al-Forghan, verse 58, we read: "And trust on that alive [God] who never dies". Also, Quran, chapter al-Ekhlas (Tohid), verse 3 says: "[God] does not give birth and is not born". These have a connection to the fact in Hinduism that Brahman neither is created nor dies.

\subsection{Connection to Islamic Mysticism (Sufism)}

Hinduism and Islamic mysticism (Sufism) have a lot in common (Zaehner, 2016), although there are important differences. Islamic mysticism (Knysh, 2010) is concentrated on the pantheism and love, which are related to the concept of non-dualism and path of love in Hinduism, respectively. Islamic mysticism includes seven stages for a mystic to progress. These stages are (1) search, (2) love, (3) knowledge, (4) contentment, (5) unity, (6) wonderment, and (7) true poverty and absolute nothingness of self (Attar, 2003). The stages of love and knowledge are related to the paths of love and knowledge in Hinduism, respectively. Note that love is before knowledge in Islamic mysticism as it is easier; Hinduism also approves that the path of love is the fastest and easiest path (see Section 5.6.2). Moreover, Islamic mysticism combines several stages and paths together in order to avoid the risks for only a single path (see Section 5.6).

Islamic mysticism believes in pantheism. The stages of unity and true poverty have strong connection to the nondualism in Hinduism, although there are some differences. The first difference is that, as will be mentioned in Section 9.2.1, non-dualism and pantheism have some difference, i.e., the former focuses on merely existence of God and nothing else while the latter concentrates on the immanent God who is in and through everything. Another small difference of Islamic mysticism and Hinduism is that the mystic progresses during the seven stages to finally gain absolute nothingness of self and be absorbed in God; however, Hinduism says there is no concept of progress as you are already That! It is noteworthy that there is a Persian proverb about mysticism which says "In the house, two people do not fit. If there is somebody in the house, one is enough". This means that there is only God and nothing else. clearly, this has the non-dualism approach of Hinduism.

There is a possibility that Islamic mysticism has borrowed the concept of monism and pantheism from Hinduism or has been affected by that. This claim gets stronger when we see the geographic closeness of India and source of Islamic mysticism. The source of fear-based and lovebased approaches of Islamic mysticism were al-Ghazali (Watt, 1953; Garden, 2014; Smith, 1944) and Abu-Saeed Abolkhayr (see the book "The Mysteries of Unification"), respectively. Al-Ghazali and Abu-Saeed Abolkhayr were born in Tus located in Khorasan (in north-east of current Iran) and Mehineh located in current Turkmenistan, respectively. Moreover, the great Persian poet and mystic, Attar (Lewisohn \& Shackle, 2006), was born in Nishapur located in Khorasan. Another famous poet and mystic was Rumi who developed the love-based mysticism of AbuSaeed Abolkhayr (Banani et al., 1994). Rumi was born in Balkh located in current Afghanistan. Also, Sanai Ghaznavi, who brought the mystical concepts into Persian po- 
etry (De Bruijn, 2014), was born in Ghazni of Afghanistan. As can be seen, the source locations of Islamic mysticism, which are Khorasan, Turkmenistan, and Afghanistan, are all close to current India, the source of Hinduism. Note that Pakistan was a part of India and has been separated from India recently. This analysis shows that Islamic mysticism may have been impacted by the concept of non-dualism in Hinduism and this impact is actually a blessed effect.

Example 41. Boostan of Saadi (Saadi Shirazi, 2003), Chapter 2: Shibli was a mystic (Avery, 2014). He bought a bag of wheat from a city which was far away from his village. When he came back home, he saw an ant in the bag. He blamed himself why he has taken the ant away from its homeland. Hence, he went back all to the town again and released the ant there to find its nest. This shows how much the mystics loved everyone and everything.

Example 42. (Attar, 1905): Mansur al-Hallaj was a Muslim mystic who stated that "I am the Truth" or "I am God". He said this because he could not see anything but God and he was merged into God as the last stage of mysticism. However, the public did not understand his view and executed him in a very harsh way. His prospective is closely related to the phrase "You are That!" in Hinduism.

\subsection{Connection to Zoroastrianism}

Zoroastrianism is a religion originated in ancient Iran (Dhalla, 1938). Zoroaster (Jackson, 1899) was the prophet who told people to listen to his teachings, think to them, and judge his teachings by their wisdom. Wisdom is a very key concept in Zoroastrianism (Curnow, 2010). This shows the connection of Zoroastrianism to the path of knowledge in Hinduism.

Zoroastrianism has a threefold path of Asha which is $\mathrm{Hu}-$ mata, Huxta, Huvarshta (Good Thoughts, Good Words, Good Deeds). Human should have good thoughts and avoid bad, negative, and poisoned thoughts. Also, human should speak good words and should not lie. Moreover, human should have good deeds and attitudes. Having good thoughts in Zoroastrianism has connection to the path of mind. The good words and deeds in Zoroastrianism have connections to the path of work.

Moreover, in Section 4.6, we saw that Hinduism says: "The truth is one but the wise call it in different ways". Zoroastrianism has a similar sentence which is: "The way is one in the world and that is the truth". This is another connection between Zoroastrianism and Hinduism.

\section{Connection to Some Other Philosophies}

Hinduism is a religion based on reasoning and logic. Therefore, sometimes, it is referred to as the Hindu philosophy. Hence, it has many connections to Greek, western, and Islamic philosophies.

\subsection{Connection to the Greek Philosophy}

The concept of monism also exists in the ancient Greek philosophy (Rist, 1965). Therefore, there can be found many connections between Hinduism and Greek philosophy.

\subsubsection{Connection to Plato's Philosophy}

Plato's theory of Forms or Ideas (Ross, 1953) states that the beings in the physical world have essences in the world of Ideas and these essences are named Forms or Ideas. The beings and matter imitate their Ideas and are not as true as them. In the Allegory of the Cave explained in Plato's Republic (Bloom \& Kirsch, 2016), Plato describes the theory of ideas using a story where some people are jailed in a cave and only see the shadows of objects on the wall. The shadows are for the real objects or Ideas which are outside of the cave. Someone who gets free of the cave tells the truth to the jailed people but they do not believe him because of their ignorance and habit. The theory of ideas is closely related to the non-dualism approach in Hinduism which states that the matter and physical world are merely appearance and ignorance.

\subsubsection{CONNECTION TO ARISTOTLE's Philosophy}

Aristotle refutes the theory of Forms (Cherniss, 1944) and approaches God and matter in another way. In his Metaphysics book, he introduces the unmoved mover or the prime cause which moves or causes other things in the universe. In the book 12 (Lambda) of Metaphysics, he describes the unmoved mover as the self-contemplation and the active intellect. The fact that Aristotle describes the unmoved mover or God as the intellect has close connection to Hinduism which introduces God as the consciousness or intellect.

\subsubsection{Connection to Plotinus' Philosophy}

Plotinus stated that there is a One which is beyond all categorizations and characterizations (Bussanich et al., 1988). However, he believed that the One is pure and sheer and thus is not an existing being. This One is the source of the world, being, and non-being. He also introduces Henosis which means union with the One. If a human goes back to the state of not having a built-in mental content, which is called Tabula Rasa, as in his birth state, he will reach Henosis and become unified with the One. In other words, a pure mind is required to get one with the One. Example 28 shows the connection of Plotinus' Philosophy to the path of mind in Hinduism.

\subsection{Connection to the Western Philosophy}

\subsubsection{CONNECTION TO MONISM, PANTHEISM, AND SPINOZA's PHILOSOPHY}

Monism and pantheism refer to "all is one" and "all is God", respectively (Levine, 2011). If that only one is considered to be God, these two terms are equivalent. In par- 
ticular, pantheism states that everything is identical with divinity. In western philosophy, pantheism was first proposed by Baruch Spinoza (Dewey, 1882). In his Ethics, Spinoza refuted René Descartes' mind-body dualism and explained that the body, soul, substance, and everything are the same and one which is called God or nature. Later on, Albert Einstein also believed in pantheism (Naess, 1983) and stated that "the past, present, and future are an illusion" (Isaacson, 2011).

The non-dualism approach in Advaita Vedanta school of Hinduism has a connection to pantheism and Spinoza's Philosophy, although there are important differences between non-dualism and pantheism. Pantheism states that God is in and through everything, i.e., God is immanent. However, non-dualism in Hinduism states that God alone is and everything is not. Note that the difference of pantheism and qualified monism (Vishishtadvaita) in Hinduism is that pantheism does not attach any attribute apart from the living and non-living beings to God but Vishishtadvaita considers some auspicious attributes for Ishvara in addition to the Chit and Achit (see Section 6.7.2).

\subsubsection{Connection to René Descartes' PHILOSOPHY}

René Descartes proposed the theory of mind-body dualism where the body and mind are taken separately. In this sense, there is no any connection with Hinduism because even in dualism (Dvaita) approach of Hinduism, matter and soul are taken separately but mind is considered as matter and different from very self (soul or Atman) in Hinduism. However, Descartes associated consensuses with mind (Robinson, 2018) which is not the case in Hinduism.

Moreover, Descartes' famous statement is "Cogito, ergo sum" meaning that "I think, therefore I am" (Descartes, 1979; 2019). Hinduism's criticism to this statement is that thinking is presumed in this claim, but why? What is thinking? This criticism aside, there is a connection between this statement and the path of knowledge in Hinduism. Except that assumption, Descartes doubted everything and tried to build his philosophy out of no assumption. This is the same approach in path of knowledge and also Nyaya logic in Hinduism.

\subsubsection{CONNECTION TO HEgELIANISM}

Hegelianism is the philosophical doctrine of Georg Wilhelm Friedrich Hegel (Taylor, 1975). In contrast to Kant's theory which said that the essence of object cannot be understood by human, Hegel's theology stated that Human can understand God and substance. Hegel believed that the process of reality is thought by God and this thought is manifested in human's philosophical comprehension. Whatever God creates is God Himself as He is manifested in the creation. This has a close connection to non-dualism approach of Advaita Vedanta in Hinduism which states there is nothing but God.

Hegel defined three different motions and developments for beings. These motions are thesis (in itself), antithesis (out of itself), and synthesis (in and for itself). That is while there is no concept of motion in Hinduism because the beings are already That and everything is not but God.

Furthermore, Hegel believes that causality is not a proper tool for explaining the world and God. In order to interpret the world, reasoning and inference should be used and not causality. That may have some connection to Hinduism which states that there is no world and thus discussing its causation is not the case.

\subsubsection{Connection to Arthur Schopenhauer's PHILOSOPHY}

Arthur Schopenhauer was a German philosopher who was highly impacted by Buddhism and Hinduism. He had a pessimistic perspective to life. In one of his important books (Schopenhauer, 1818), he discusses human's will and consciousness. One of his famous quotes about life is: "Life swings like a pendulum backward and forward between pain and boredom". Like Buddha, he also found out that joy is not the opposite state of suffering; however, boredom is the opposite of suffering. In life, human suffers from not having something, tries a lot to gain it. When he gains it, we enjoys it for a very short time, and then starts to be bored of having it. Then, he suffers from not having another thing and this cycle repeats. Therefore, joy is just a very short state between suffer and boredom. This prospective of Schopenhauer to life has clear connections with Buddhism. Moreover, Schopenhauer discusses consciousness very similarly to Hinduism's perspective because of being impacted by the Hindu philosophy.

\subsection{Connection to Islamic Philosophy}

\subsubsection{CONnECTION TO AVICEnNA's PHILOSOPHy}

Avicenna was one of the most important Islamic philosophers (Inati, 2014). Initially, he followed Aristotle but later in his life, he followed Plato and Plotinus and tended to mysticism. In Islamic theology, his Proof of the Truthful is well-known for the claim of existence of God. Avicenna analyzed that the existence of beings cannot be because of essence of the existing beings but it must be because of the essence of an existent God which gives the existence to the essence of beings. Although Avicenna believed in separate God and beings, but his analysis of essence and existence has connection to Hinduism. He said that the beings owe their existence to the essence of God and Hinduism also says that this world and the beings borrow their existence from God. However, Hinduism goes further in discussion and says that this existence is just ignorance and there is no existence of the world.

Moreover, in the chapters eight and nine of the second book 
in his Al-Isharat Wa-Al-Tanbihat (Sina \& Donya, 1947), Avicenna explains and analyzes mysticism. He discusses the bliss of it and also the stages of mysticism. In this way, he also has some connection to the concept of non-dualism in Hinduism.

\subsubsection{CONNECTION TO SUHRAWARdi's PHILOSOPHY}

Shahab al-Din Suhrawardi (Marcotte, 2007) was the founder of the school of Illumination (Ishraqi) (Razavi, 2014) in Islamic philosophy. This school states that everything in the world is light or illumination and there is nothing but light. The beings and objects, which are all lights, shine to one another. On the other hand, Quran (Pickthall, 1973), chapter an-Noor (light), verse 35, states: "God is the light of skies and the earth". Therefore, everything is God in the school of Illumination connecting it to the pantheism in a mystical approach. Although Hinduism states that everything is nothing and only God is, the school of Illumination has some connection to the non-dualism approach of Hinduism.

\subsubsection{Connection to Mulla Sadra's Philosophy}

Mulla Sadra (Rahman, 1975) was the founder of Transcendent Theosophy (Kamal, 2016) in Islamic philosophy. His well-known book is named "The Transcendent Philosophy of the Four Journeys of the Intellect". Similar to Avicenna, Mulla Sadra asserted that existence precedes essence meaning that the existence of beings which have essence requires an existent being which is a necessary being and is called God. In his Transcendent philosophy, he stated that the beings share existence while their essences differ. Because of difference of essences, they have different characteristics. For example, characteristics of stone, plant, animal, and human are different. In the sense that he believed in shared existence of beings, he is connected to Hinduism as Hinduism states that only God exists. Also, in the sense that Mulla Sadra discusses different characteristics, his thoughts are close to the path of mind and categories of the subtle body in Hinduism (see Section 5.4.3).

Mulla Sadra also defines the Substantial Motion (Haq, 1972). He states that movement exists not only in physics of beings but also in their essence. Every being has a self flow which moves toward improvement and completeness as much as its essence allows. Hinduism, however, has another perspective which is there is no movement because all beings are not and only God is. For example, there is no need for human to progress as human is already That; the human is merely ignorance.

\section{Conclusion}

In this paper, we saw that Hinduism accepts the other religions and categorizes them as special cases in Hinduism. Not only does not it reject other religions, but also it states that the other religions are correct and sufficient for salva- tion. The difference is in the perspectives of religions to to the truth but they are all aiming and saying the same thing (see Example 38). Hinduism says "the truth is one but the wise call it in different ways". Every wise may see the truth partially as the truth is huge and beyond understanding of humans (see Example 37); hence, religions limit the truth to the capacity of society to understand.

As was mentioned in Section 5.6, a human can reach the ultimate enlightenment and salvation by following merely one path; however, there exist some risks for every path. Different religions, although follow different paths in different relative portions, have mostly focus on one of the paths of knowledge, love, mind, and work. For example, the focus of Christianity is path of love. Hence, in order to avoid any possible risk for every single path (see Section 5.6), it might be better to remove the bias on a specific religion and follow all the holy religions. The religions are saying the same thing and have the same goal. We can make use of all of them for reaching salvation. Again, note that every holy religion is completely respectful and suffices by itself for salvation, although it may have some risks (see Section 5.6). A human can accept all the holy religions but focus more on one of the them. The point of this paragraph is just it is better to remove bias on a specific religion and not fall in selfishness (in the sense that "my religion is correct and other religions are false"). Therefore, if there is some very good point in another religion, human can get and use it happily without bias. This is what makes the religions close to one another and can avoid fights between beliefs. In the last few days of his life, in an interview, Bertrand Russell (Roberts, 2013) recommended to people to respect each others' opinions and beliefs.

One of the many aspects that the religions share is that most of them explain and preach pantheism and non-dualism. For example, Christianity says: "Don't you believe that I am in the Father, and that the Father is in me? The words I say to you, I do not speak on my own authority. Rather, it is the Father, living in me, who is doing his work.", Islamic mysticism talks about unification, pantheism, and "there is only one in the house and not two", and Islamic illumination theory and Quran say that God is the light and everything is light so God is through everything. Also, Zoroastrianism states: "The way is one in the world and that is the truth". Buddhism also believes in monism and says everything is one but that one is nothing or voidness. The non-dualism and qualified monism approaches in Hinduism also have close concepts to pantheism (see Section 9.2.1 for similarities and differences).

Another shared concept in the religions is the victory of good against bad and having a savior. The savior has different names in religions; for example, his name is Messiah, Jesus Christ, Mahdi, Saoshyant, and Kalki in Judaism, Christianity, Islam, Zoroastrianism, and Hinduism, respec- 
tively. But the more interesting thing is that the deep meaning of apocalypse in all the religions is like a metaphor for the fight of good and evil in every single person. This fight is actually personal and inside everyone. The moment that a human gets enlightened and wins his intrinsic fight, apocalypse happens for him and he is freed.

Note that gaining the knowledge of "God alone is and everything is not" is not sufficient for enlightenment. It should be brought into practice.

\section{Acknowledgments}

We thank the great teacher of Hinduism, Adi Shankara (Shankaracharya) (years 788-820 CE), for his great explanations of the profound Hinduism. We also thank different Hinduism teachers such as Swami Vivekananda, Swami Atmarupananda, and Swami Sarvapriyananda (Ramakrishna Order) for their great teachings.

\section{References}

Acharya, Madhava. The Sarva-Darsana-Samgraha: Review of the Different Systems of Hindu Philosophy. Library of Alexandria, 1978.

Al-Ghazali, Abu Hamid. Deliverance from error. Louisville: Fons Vitae, 2000.

Amin, Arati, Kumar, Sai Sailesh, Rajagopalan, Archana, Rajan, Supriya, Mishra, Soumya, Reddy, Udaya Kumar, and Mukkadan, Joseph Kurien. Beneficial effects of OM chanting on depression, anxiety, stress and cognition in elderly women with hypertension. Indian Journal of Clinical Anatomy and Physiology, 3(3):253-255, 2016.

Arberry, Arthur John. Tales from the Masnavi. Routledge, 2013.

Attar, Farid al-Din. Tadhkirat al-Awliya. Ed. RA Nicholson. London, 1905.

Attar, Farid Ud-Din. Conference of the Birds. Interlink Books, 2003.

Avery, Kenneth. Shibli: His Life and Thought in the Sufi Tradition. State University of New York Press, 2014.

Banani, Amin, Hovannisian, Richard, and Sabagh, Georges. Poetry and mysticism in Islam: The heritage of Rumi, volume 11. Cambridge University Press, 1994.

Barua, Beni Madhab. A history of pre-Buddhistic Indian philosophy. Motilal Banarsidass Publishers, 1970.

Beck, Guy L. Sonic theology: Hinduism and sacred sound. Motilal Banarsidass Publ., 1995.

Bhawuk, Dharm. Spirituality and Indian Psychology: Lessons from the Bhagavad-Gita. Springer Science \& Business Media, 2011.
Bible, Holy. New international version. Grand Rapids: Zondervan, 1984.

Bloom, Allan and Kirsch, Adam. The Republic of Plato. Basic Books, 2016.

Bronkhorst, Johannes. Mīmāmsāa and Vedānta: interaction and continuity, volume 10. Motilal Banarsidass Publishers, 2007.

Bronkhorst, Johannes. Free will and Indian philosophy. Antiqvorvm Philosophia, 6:19-29, 2012.

Brown, W Norman. The sanctity of the cow in Hinduism. The Madras University Journal, 28(2):29-49, 1957.

Bühler, Georg. The laws of Manu, volume 25. Clarendon Press, 1886.

Bussanich, John $\mathrm{R}$ et al. The One and its Relation to Intellect in Plotinus: A commentary on selected texts, volume 49. Brill, 1988.

Chalmers, David. The hard problem of consciousness. The Blackwell companion to consciousness, pp. 225235, 2007.

Chalmers, David J. Facing up to the problem of consciousness. Journal of consciousness studies, 2(3):200-219, 1995.

Chandra, Suresh. Encyclopaedia of Hindu gods and goddesses. Sarup \& Sons, 1998.

Cherniss, Harold Fredrik. Aristotle's Criticism of Plato and the Academy, volume 1. Johns Hopkins Press Baltimore, 1944.

Chopra, Deepak. The path to love: Spiritual strategies for healing. Harmony, 2007.

Churchland, Paul M. Matter and consciousness. MIT press, 2013.

Cioran, EM and Brown, Frederick. Encounter with the void. The Hudson Review, 23(1):37-48, 1970.

Countryman, Louis William. The mystical way in the Fourth Gospel: Crossing over into God. Fortress Press Philadelphia, PA, 1987.

Cowen, Ron. Simulations back up theory that universe is a hologram. Nature News, 2013.

Curnow, Trevor. Wisdom in the ancient world. A\&C Black, 2010.

Dallmayr, Fred. Nothingness and suunyatā: a comparison of Heidegger and Nishitani. Philosophy East and West, pp. 37-48, 1992. 
Das, Bhumipati. Sri Kalki Purana. Calcutta, Bangiya Sahitya Parishat, 1913.

Dasgupta, Surendranath. Hindu mysticism. Motilal Banarsidass Publishers, 1983.

Dasgupta, Surendranath. Yoga as philosophy and religion. Routledge, 2013.

Datta, Dhirendra Mohan. The Philosophy of Mahatma Gandhi. University of Wisconsin Press Madison, 1953.

De Bary, William Theodore. Sources of Indian tradition. Columbia University Press, 1958.

De Bruijn, Johannes Thomas Pieter. Persian Sufi poetry: an introduction to the mystical use of classical Persian poems. Routledge, 2014.

Derrida, Jacques. Telepathy. Oxford Literary Review, 10 (1):3-41, 1988.

Descartes, René. Discourse on method, 1979.

Descartes, René. The principles of philosophy. BookRix, 2019.

Deshpande, Manohar Springiwas. Light of India: The Message of the Mahatma. Wilco Publishing House, 1958.

Deussen, Paul. The philosophy of the Upanishads, volume 2. Dover publications, 1906.

Dewey, John. The pantheism of Spinoza. The Journal of Speculative Philosophy, 16(3):249-257, 1882.

Dhalla, Maneckji Nusservanji. History of Zoroastrianism. Oxford University Press, 1938.

Dikshitar, VR Ramachandra. War in ancient India. Genesis Publishing Pvt Ltd, 1999.

Doniger, Wendy. On Hinduism. Oxford University Press, 2014.

Doniger, Wendy and O'Flaherty, Wendy Doniger. Karma and rebirth in classical Indian traditions. University of California Press, 1980.

Dundas, Paul. The Jains. Routledge, 2003.

Einstein, Albert. On the electrodynamics of moving bodies. Annalen der Physik, 17(891):50, 1905.

Einstein, Albert. The field equations of gravitation. Sitzungsber. Preuss. Akad. Wiss. Berlin (Math. Phys.), 1915:844-847, 1915.

Einstein, Albert. Science and religion. Nature, 146(3706): 605-607, 1940.
Fischer, Louis and De Kock, G. The Life of Mahatma Gandhi. J. Cape, 1951.

Fischler, Willy and Susskind, Leonard. Holography and cosmology. arXiv preprint hep-th/9806039, 1998.

Flood, Gavin D. An introduction to Hinduism. Cambridge University Press, 1996.

Garden, Kenneth. The first Islamic reviver: Abu Hamid alGhazali and his revival of the religious sciences. Oxford University Press, 2014.

Giordan, Giuseppe and Pace, Enzo. Religious Pluralism: Framing Religious Diversity in the Contemporary World. Springer, 2014.

Gödel, Kurt. Über formal unentscheidbare sätze der principia mathematica und verwandter systeme i. Monatshefte für mathematik und physik, 38(1):173-198, 1931.

Goldman, Robert P and Goldman, Sally J Sutherland. The Ramayana of Valmiki, volume 6. Princeton University Press, 2009.

González-Reimann, Luis. The coming golden age: On prophecy in Hinduism. In Prophecy in the New Millennium, pp. 121-138. Routledge, 2016.

Gray, Jeffrey Alan. Consciousness: Creeping up on the hard problem. Oxford University Press, USA, 2004.

Grimes, John A. The Seven Great Untenables: Sapta-vidhā Anupapatti. Motilal Banarsidass Publishers, 1990.

Gupta, Ravi and Valpey, Kenneth. The Bhagavata Purana: sacred text and living tradition. Columbia University Press, 2013.

Hanada, Masanori, Hyakutake, Yoshifumi, Ishiki, Goro, and Nishimura, Jun. Holographic description of a quantum black hole on a computer. Science, 344(6186):882885, 2014.

Haq, Muhammad 'Abdul. Mullā Sadrā's concept of substantial motion. Islamic Studies, 11(2):79-91, 1972.

Hari, Syamala. How Vedanta explains conscious subjective experience. Scientific GOD Journal, 6(5), 2015.

Harrelson, Walter J. The ten commandments and human rights. Mercer University Press, 1997.

Hawking, Stephen. A brief history of time: from big bang to black holes. Random House, 2009.

Herbert, Patricia M. The life of the Buddha. Pomegranate, 2005. 
Herman, Arthur L. Religions as failed theodicies: atheism in Hinduism and Buddhism. In Indian Philosophy of Religion, pp. 35-60. Springer, 1989.

Humphreys, Christmas. Zen Buddhism. Heinemann, 1949.

Hyakutake, Yoshifumi. Quantum near-horizon geometry of a black 0-brane. Progress of Theoretical and Experimental Physics, 2014(3):033B04, 2014.

Ichimura, Shōhei. Buddhist critical spirituality: Prajñā and Śūnyatā. Motilal Banarsidass Publishers, 2001.

Inati, Shams C. Ibn Sina's Remarks and Admonitions: Physics and Metaphysics: An Analysis and Annotated Translation. Columbia University Press, 2014.

Isaacson, Walter. Einstein: His life and universe, 2011.

Jackendoff, Ray. Consciousness and the computational mind. The MIT Press, 1987.

Jackson, Abraham Valentine Williams. Zoroaster: the prophet of ancient Iran. Macmillan, 1899.

Kamal, Muhammad. Mulla Sadra's transcendent philosophy. Routledge, 2016.

Kaufman, Whitley RP. Karma, rebirth, and the problem of evil. Philosophy East and West, pp. 15-32, 2005.

Keyes, Charles F, Daniel, E Valentine, et al. Karma: An anthropological inquiry. Univ of California Press, 1983.

Klostermaier, Klaus K. A survey of Hinduism. State University of New York Press, 2007.

Knysh, Alexander. Islamic mysticism: A short history, volume 1. Brill, 2010.

Krishna, Nanditha. Sacred animals of India. Penguin Books India, 2010.

Kumar, Sanjay, Nagendra, HR, Manjunath, NK, Naveen, $\mathrm{KV}$, and Telles, Shirley. Meditation on OM: Relevance from ancient texts and contemporary science. International journal of yoga, 3(1), 2010.

Lakin, Patricia. Steve Jobs: Thinking Differently. Simon and Schuster, 2015.

Landaw, Jonathan. Prince Siddhartha: the story of Buddha. Simon and Schuster, 2011.

Larson, Gerald James. Classical Sāṃkhya: An interpretation of its history and meaning. Motilal Banarsidass Publ., 2001.

Law, Bimala Churn. Mahavira: his life and teachings. Luzac, 1937.
Levine, Michael. Pantheism. Stanford Encyclopedia of Philosophy, 2011.

Lewis, David. Causation. The journal of philosophy, 70 (17):556-567, 1974.

Lewisohn, Leonard and Shackle, Christopher. Attar and the Persian Sufi Tradition: The Art of Spiritual Flight. Bloomsbury Publishing, 2006.

Libet, Benjamin. Solutions to the hard problem of consciousness. Journal of Consciousness Studies, 3(1):3335, 1996.

Libet, Benjamin. Do we have free will? Journal of consciousness studies, 6(8-9):47-57, 1999.

Loughnan, Steve, Bratanova, Boyka, and Puvia, Elisa. The meat paradox: How are we able to love animals and love eating animals? The Inquisitive Mind Italia, 1:15-18, 2012.

Mann, Thomas W. The book of the Torah. Wipf and Stock Publishers, 2013.

Marcotte, Roxanne. Suhrawardi. The Stanford Encyclopedia of Philosophy, 2007.

Marwaha, Sonali Bhatt. Colors of Truth: Religion, Self and Emotions: Perspectives of Hinduism, Buddism, Jainism, Zoroastrianism, Islam, Sikhism and Contemporary Psychology. Concept Publishing Company, 2006.

Mascaró, Juan. The Bhagavad Gita, volume 121. Penguin, 2003.

Mathew, Oruvattithara Mathew. The concept of avatar or avatara (incarnation) in hinduism. Annales de philosophie et des sciences humaines, 2005.

Mayr, Ernst. Animal species and evolution. Harvard University Press, 1963.

McFadden, PL and Skenderis, Kostas. The holographic universe. In Journal of Physics: Conference Series, volume 222. IOP Publishing, 2010.

McLeod, William Hewat. The A to Z of Sikhism, volume 45. Scarecrow Press, 2009.

Menon, Y Keshava. The Mind of Adi Shankaracharya. Jaico Publishing House, 2004.

Moore, Andrew. Meditation. The Rosen Publishing Group, Inc, 2008.

Morozov, A Yu. String theory: What is it? Soviet Physics Uspekhi, 35(8):671, 1992. 
Naess, Arne. Einstein, spinoza, and god. In Old and New Questions in Physics, Cosmology, Philosophy, and Theoretical Biology, pp. 683-687. Springer, 1983.

Narayan, Roopa Hulikal. Nyaya-Vaisheshika: The Indian tradition of physics. arXiv preprint physics $/ 0701077$, 2007.

Nasr, Seyyed Hossein and De Santillana, Giorgio. Science and civilization in Islam, volume 16. Harvard University Press Cambridge, MA, 1968.

Phillips, Stephen H. Yoga, karma, and rebirth: A brief history and philosophy. Columbia University Press, 2009.

Phillips, Stephen H. Epistemology in classical India: The knowledge sources of the Nyaya school. Routledge, 2013.

Pickthall, Mohammed Marmaduke. The meaning of the glorious Quran. Islamic Call Society, 1973.

Potter, Karl H. Advaita Vedānta up to Śamkara and his Pupils, volume 3. Motilal Banarsidass Publ., 1970.

Prasad, Ramanuj. Know The Puranas. Pustak Mahal, 2007.

Prophet, Mark L and Prophet, Elizabeth Clare. The Path to Immortality. Summit University Press, 2006.

Puligandla, Ramakrishna. Fundamentals of Indian philosophy. Abingdon Press, 1975.

Quine, Willard V. Philosophy of logic. Harvard University Press, 1986.

Rahman, Fazlur. The Philosophy of Mulla Sadra Shirazi. State University of New York Press, 1975.

Ranganathan, Shyam. Ramanuja. Internet Encyclopedia of Philosophy, 2004.

Rao, DS. The Mahabharata of Vyasa. Indian Literature, 24(2):97-109, 1981.

Razavi, Mehdi Amin. Suhrawardi and the School of Illumination. Routledge, 2014.

Rist, John M. Monism: Plotinus and some predecessors. Harvard Studies in Classical Philology, 69:329344, 1965.

Roberts, George W. Bertrand Russell memorial volume. Routledge, 2013.

Robinson, William S. Dualism. In The Routledge Handbook of Consciousness, pp. 51-63. Routledge, 2018.

Ross, David. Plato's theory of ideas. Revue Philosophique de la France Et de l'Etranger, pp. 455-456, 1953.
Rumi, Jalal al-Din. The Masnavi, Book Two. Oxford University Press, 2008a.

Rumi, Jalal al-Din. The Masnavi, Book One. Oxford University Press, 2008b.

Rumi, Jalal al-Din. The Masnavi, Book Three. Oxford University Press, 2013.

Saadi Shirazi, M. Boostan. Tehran: Al-Khwarizmi Publication, 2003.

Samuel, Geoffrey. The body in Buddhist and Hindu tantra: some notes. Religion, 19(3):197-210, 1989.

Sarma, Deepak. An Introduction to Madhva Vedanta. Routledge, 2017.

Schopenhauer, Arthur. The World as Will and Representation. 1818.

Schrödinger, E. About heisenberg uncertainty relation. Proc. Prussian Acad. Sci. Phys. Math. XIX, 293, 1930.

Sharma, Ursula. Theodicy and the doctrine of karma. Man, 8(3):347-364, 1973.

Shastri, Dakshinaranjan. Charvaka Philosophy. Purogami Prakashani, 1967.

Sina, Abi Ali Ibn and Donya, Solayman. al-Isharat wa-ttanbihat. Ihya Al-Kutub Al- Arabiyah, 1947.

Singh, Nirbhai. Philosophy of Sikhism: Reality and its manifestations. Atlantic Publishers \& Distri, 1990.

Smith, Margaret. Al-Ghazali, the mystic. Luzac London, 1944.

Soltes, Ori Z. Mysticism in Judaism, Christianity, and Islam: Searching for Oneness. Rowman \& Littlefield, 2009.

Spencer, Colin. The heretic's feast: A history of vegetarianism. University Press of New England, 1996.

Sproul, Robert Charles. The mystery of the Holy Spirit. Tyndale House Publishers, Inc., 1994.

Stevenson, Ian. Children Who Remember Previous Lives: A Question of Reincarnation. McFarland, 2000.

Stoop, David. You are what you think. Fleming H. Revell, 2003.

Sumedho, Ajahn. The four noble truths. Amaravati Buddhist Monastery, 1992.

Susskind, Leonard. The world as a hologram. Journal of Mathematical Physics, 36(11):6377-6396, 1995. 
Syman, Stefanie. The subtle body: The story of yoga in America. Farrar, Straus and Giroux, 2010.

Talbot, Michael. The holographic universe, 1991.

Taylor, Charles. Hegel. Cambridge University Press, 1975.

Torwesten, Hans and Rosset, Loly. Vedanta: Heart of Hinduism. Grove Press, 1994.

Van Inwagen, Peter. An essay on free will. Oxford University Press, 1983.

Vidyabhusana, Satis Chandra. A history of Indian logic: Ancient, mediaeval and modern schools. Motilal Banarsidass Publishers, 1988.

Vireswarananda, Swami. Brahma-sutras. Almora, Himalayas, Advaita ashrama, 1936.

Von Glasenapp, Helmuth. Jainism: An Indian religion of salvation, volume 14. Motilal Banarsidass Publishers, 1999.

Watt, William Montgomery. The faith and practice of alGhazali. Allen \& Unwin, 1953.

Werner, Marta L. Signals from a distance: editing, telepathy, elegy. Textual Cultures, 3(1):3-11, 2008.

Wilkins, William Joseph. Hindu mythology. Thacker, Spink, 1913.

Yano, Michio. Calendar, astrology, and astronomy. The Blackwell Companion to Hinduism, pp. 376-392, 2003.

Zaehner, Robert Charles. Hindu and Muslim mysticism. Bloomsbury Publishing, 2016. 